The PATCH Lab: A database and workspace for Cenozoic terrestrial paleoclimate and environment reconstruction

Tyler Kukla*1,2, Jeremy K. C. Rugenstein ${ }^{2}$, Elizabeth Driscoll ${ }^{2}$, Daniel E. Ibarra ${ }^{3}$, and C. Page Chamberlain ${ }^{1}$

${ }^{1}$ Department of Geological Sciences, Stanford University, Stanford, CA 94305, USA

${ }^{2}$ Department of Geosciences, Colorado State University, Fort Collins, CO 80523, USA

${ }^{3}$ Institute at Brown for Environment and Society and Department of Earth, Environmental, and Planetary Science, Brown University, Providence, RI 02912, USA

February 2022

Non-peer reviewed preprint article submitted to EarthArXiv.

Manuscript submitted to American Journal of Science

*contact: tykukla@colostate.edu 
Draft VERsion February 3, 2022

\title{
The PATCH Lab: A database and workspace for Cenozoic terrestrial paleoclimate and environment reconstruction
}

Tyler Kukla, ${ }^{1,2}$ Jeremy K. C. Rugenstein, ${ }^{2}$ Elizabeth Driscoll,${ }^{2}$ Daniel E. Ibarra, ${ }^{3}$ and C. Page Chamberlain ${ }^{1}$

\author{
${ }^{1}$ Department of Geological Sciences \\ Stanford University \\ Stanford, CA 94305, USA \\ ${ }^{2}$ Department of Geosciences \\ Colorado State University \\ Fort Collins, CO 80523, USA \\ ${ }^{3}$ Institute at Brown for Environment and Society \\ Department of Earth, Environmental, and Planetary Science \\ Brown University \\ Providence, RI 02912, USA
}

\begin{abstract}
In the last two decades, analytical advances and a growing interest in relevant research questions has brought a rapid increase in the amount of stable isotope data used for reconstructing terrestrial paleoclimates and environments. As the spatial and temporal resolution of proxy data continues to improve, the quantitative interpretation of these data is becoming increasingly common. These advances in data resolution and theory bring opportunities for multi-proxy comparisons, synthesis and modeling of large datasets, integration with paleoecological datasets, improved climate model benchmarking, and more. Here, in an effort to support these growing avenues of research, we present The PATCH Lab (Paleo-Analysis of Terrestrial Climate and Hydrology) - an online portal to discover, download, and quantitatively analyze Cenozoic terrestrial stable isotope data. The PATCH Lab portal includes a new database that currently includes 27009 stable isotope measurements from 211 publications spanning multiple terrestrial proxies, and quantitative models for interpreting water isotope and soil carbonate data. Data query, download, and modeling results are organized into user-friendly graphical interfaces that export datasets as .csv files. New data can be easily submitted to the PATCH Lab curators through the portal by completing a data submission template. The PATCH Lab, with the help of community engagement, serves as a resource for archiving terrestrial stable isotope data, building paleo "isoscapes", and increasing accessibility to quantitative methods of investigating terrestrial stable isotopes in paleoclimate.
\end{abstract}

Keywords: Stable isotope, database, Cenozoic, terrestrial, oxygen, hydrogen, carbon

\section{INTRODUCTION}

Stable isotopes of oxygen, hydrogen, and carbon from terrestrial "proxy" materials are valuable tracers of water and climate on land throughout Earth history. In this paper, we will refer to these proxy data collectively as "terrestrial stable isotope data", although we recognize these terms cast a broader net. The terrestrial stable isotope systems mentioned above are used to address a wide array of problems spanning the growth and death of mountain ranges (Criss \& Taylor 1983; Horton and others, 2004; Mulch and others, 2006; Saylor and others, 2009; Hough and others, 2014; Cassel and others, 2018; Bershaw and others, 2019; Methner and others, 2021), patterns of past atmospheric circulation (Quade and others, 1989; Amundson and others, 1996; Zhisheng and others, 2005; Passey and others, 2009; Suarez and others, 2011; Winnick and others, 2013; Caves and others, 2015), changes in vegetation (Quade and others, 1989; Quade \& Cerling 1995; Latorre and others, 1997; Fox \& Koch 2003; Zhisheng and others, 2005; Passey and others, 2009; Mix and others, 2013; Caves and others, 2016), atmospheric $p C O_{2}$ (Cerling 1999; Ekart and others, 1999; Breecker 2013; Breecker \& Retallack 2014; Ji and others, 2018; Da and others, 2019), surface temperatures (Zanazzi and others, 2007; Hough and others, 2014; Mix \& Chamberlain 2014; Fan and others, 2018), and more. As such, 
terrestrial stable isotope tracers are some of the most widely used tools for reconstructing the history of climate, landscapes, and life.

Decades of research have generated a wealth of terrestrial stable isotope data, achieving impressive resolution over space and time and across numerous proxy systems. The publications generating these data represent immeasurable hours of field and laboratory work, and they help form the foundation of our current understanding of Cenozoic terrestrial climate, tectonics, and environments (Rowley \& Garzione 2007; Strömberg 2011; Chamberlain and others, 2012). With advances in laboratory precision and higher throughput methods, new work is rapidly building on this foundation. The high pace of data output brings exciting opportunities for terrestrial stable isotope research, as well as the growing challenge of keeping up with new results. In order to preserve the existing knowledge base and ensure old and new data remain equally accessible into the future, dataset syntheses are a useful next step.

Synthesizing these stable isotope data in a curated database carries additional benefits beyond improving data accessibility. Specifically, a database helps investigators identify and target key gaps in existing records for future studies. Having a central data repository also makes it easier to determine which data gaps are likely to provide the most new information per sampling effort. Much like pieces of a puzzle, the amount of new information that any measurement can provide is limited, but it increases when there are complementary data nearby for comparison to further constrain the plausible interpretations. Research progresses faster when it is easier to find the gaps that likely contribute most to a given research question.

Databases also amplify the role of proxy data in climate model experiments by providing a source for model benchmarking or initialization (Botsyun \& Ehlers 2021; Belem and others, 2022). Advances in the spatial and temporal resolution of data have been mirrored by theoretical advances with process-based models designed for paleo-reconstruction (Cerling 1999; Hendricks and others, 2000; Evans and others, 2013; Winnick and others, 2014; Dee and others, 2015a,b; Ibarra \& Chamberlain 2015; Caves and others, 2016; Bailey and others, 2018; Dee and others, 2018; Kukla and others, 2019). These models simulate isotopic systems while limiting the number of assumptions and free parameters, bridging the gap between empirical data and complex General Circulation Models (GCMs) or Earth System Models (ESMs). As data coverage improves, so does the utility and potential application of these models. Lastly, databases make existing data accessible to a far wider community than has traditionally utilized such data. Given the increasing ease with which stable isotopes are measured, an increasing number of Earth science subdisciplines are utilizing these measurements to constrain their research question. By making existing data available, we increase the accessibility to related subdisciplines to utilize the full panoply of constraints that terrestrial stable isotope data have provided in understanding Earth's past.

Here, we present The PATCH Lab (Paleo-Analysis of Terrestrial Climate and Hydrology) - an online platform that merges a multi-proxy terrestrial stable isotope database with quantitative models for analyzing data. Our platform is inspired by ongoing efforts in compiling large, paleo datasets such as in the SISAL database (Atsawawaranunt and others, 2018; Comas-Bru and others, 2020), Macrostrat (Peters and others, 2018), Neotoma (Williams and others, 2018), Iso2k (Konecky and others, 2020), and other compilations (Fox and others, 2018; Jolivet \& Boulvais 2021), filling a gap in pre-Quaternary terrestrial proxy data availability. The PATCH Lab includes a portal to find and download the stable isotope data, graphical user interfaces (GUIs) for oxygen (Hendricks and others, 2000; Chamberlain and others, 2014; Winnick and others, 2014; Kukla and others, 2019) and carbon (Cerling 1999; Caves and others, 2016) isotope models, and submission pages for new data, data corrections, comments, and queries. The main goals of the database and workspace are twofold: (1) to make the spatial dimension (i.e. "isoscapes") more accessible for Cenozoic terrestrial studies, and (2) to increase the accessibility of quantitative tools for paleoclimate data analysis.

\section{DATABASE OVERVIEW}

The database currently focuses on Cenozoic-age ( 66 Ma-present) sediment in North America, Europe, and Asia (Fig. 1). Ongoing work is focused on compiling data from additional continents. Despite consisting of mostly Cenozoic data, the database includes some data from the Mesozoic. It is also missing much of the youngest, Quaternary data as these have been compiled in other places such as the SISAL database for cave records (Atsawawaranunt and others, 2018; Comas-Bru and others, 2020). While these oldest and youngest intervals are underrepresented in the database, we welcome new data from these or other points in geologic time. Broadly, any terrestrial stable isotope proxy dataset including oxygen, hydrogen, carbon, clumped, and triple-oxygen isotopes is eligible to be submitted to the database.

Data were compiled from 211 publications with a total of 27009 measurements including oxygen $\left(\delta^{18} O\right)$, carbon $\left(\delta^{13} C\right)$, and hydrogen $(\delta D)$ isotopes, as well as triple-oxygen $\left(\Delta^{17} O\right)$ and carbonate clumped measurements $\left(\Delta_{47}\right)$ 


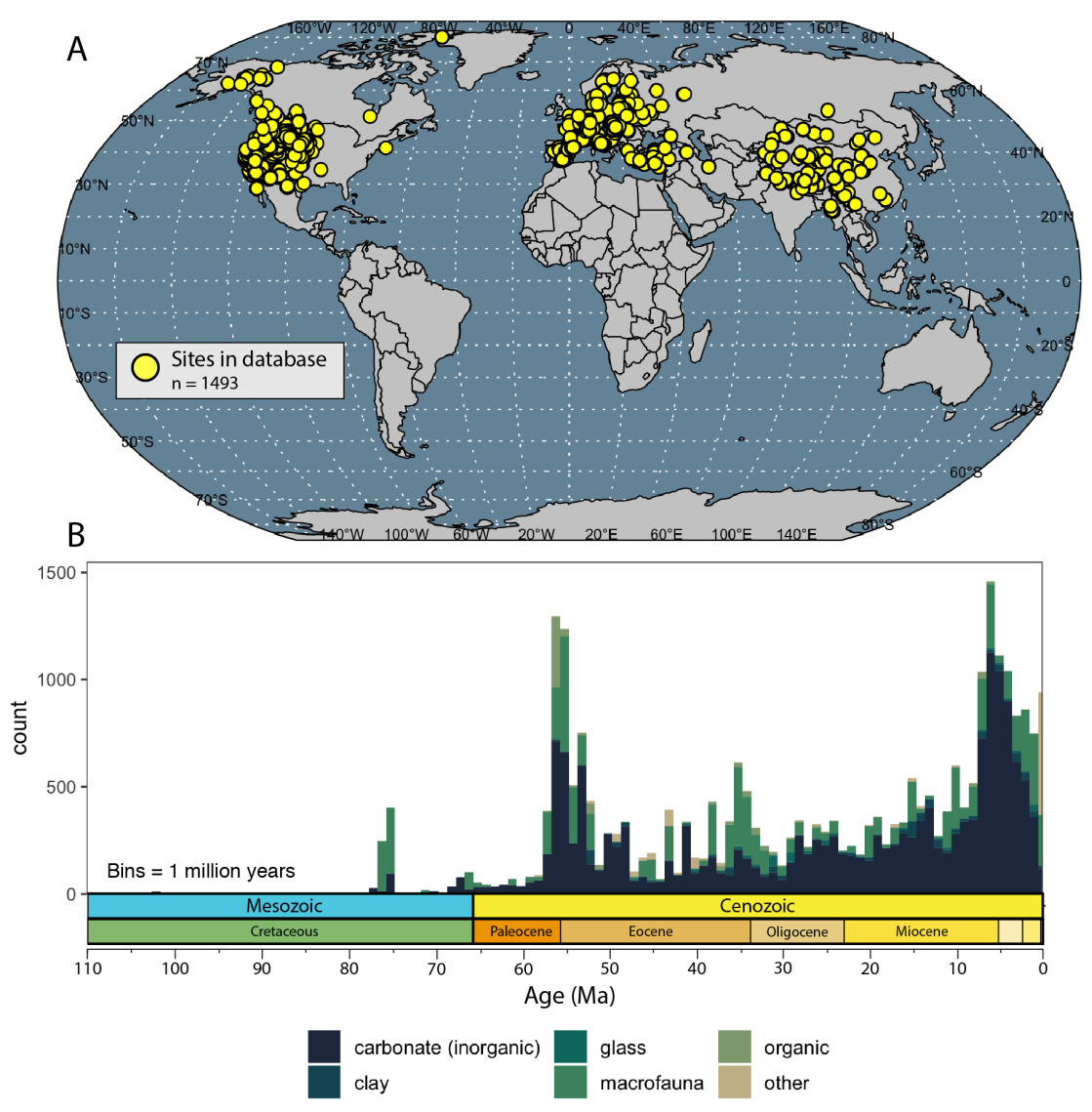

Figure 1. (A) Global map of proxy data sites represented in the database as of February, 2022. (B) Histogram of the number of isotope samples by sample type through time. Note peaks during climate events like the Paleocene-Eocene Thermal Maximum (PETM) and Eocene-Oligocene boundaries. Bins are one million years.

when available (Table 1). Of these, 24906 are $\delta^{18} O$ measurements, 22114 are $\delta^{13} C$, and 978 are $\delta D$. About $59 \%$ of the non-biogenic data comes from paleosol strata, $27 \%$ from lacustrine sediments, $2 \%$ from ashes, and $1 \%$ from altered igneous or metamorphic rock. About $23 \%$ of the data comes from biogenic material such as shells and tooth enamel.

\subsection{Proxy coverage case study: western North America}

While it is challenging to quantify the completeness of the existing data record, in North America we have the unique opportunity to compare the density of stable isotope sampling to the estimated distribution of terrestrial sediment via the Macrostrat database (Peters and others, 2018). This exercise does not inform the global coverage of stable isotope data, but it does illustrate the regional density of sample coverage and how it has increased through time (Fig. 2).

The Macrostrat database includes geographic polygons that are fixed through time and represent interpolated lithological boundaries (Peters and others, 2018). Thus, the spatial coverage of a given column is not likely to accurately represent the spatial coverage of the lithology. Instead, we can consider the areal coverage of polygons as the upper bound on the true lithological extent. Using these polygons, we extract just the terrestrial sediment lithologies through the Cenozoic to approximate the maximum potential proxy coverage for a given point in time. We note that not all stable isotope proxies are restricted to terrestrial sediments - altered igneous and metamorphic rocks have been used to infer past meteoric water isotopes, for example - but sedimentary proxies make up the vast majority of data in our database $(>98 \%)$.

When analyzing Cenozoic sediments, more than half of the terrestrial sediment polygons in western North America have been sampled for stable isotope proxy data (Fig. 2b). Together, these polygons account for up to $75 \%$ of the total areal coverage of terrestrial sediment in the mid-to-late Cenozoic (Fig. 2a). Most of the sampling of individual polygons occurred by 2010, but the few additional polygons sampled from 2010 to present account for a large fraction of the total areal coverage. This result is somewhat sensitive to the time binning used, with the percent of polygons 




Figure 2. Estimated coverage of western North America stable oxygen, hydrogen, and carbon isotope data based on comparison with terrestrial sediment in the Macrostrat database. (A) The areal coverage of polygons containing stable isotope data. (B) The fraction of polygons containing stable isotope data. Lines refer to cumulative data coverage as of a given year (ranging from 1990, beige, to 2021, dark blue) (C, D) Maps of present day dataset locations (yellow circles) overlain on Macrostrat polygons for the Paleogene (C) and Miocene (D).

and area sampled increasing with bin duration. We bin the data in 5 million year intervals because this is similar to or greater than the age uncertainty for many terrestrial sections, and consistent with the timescales considered for the tectonic evolution of mountain ranges (Chamberlain and others, 2012). The extensive sample coverage of western North America demonstrates that climate and tectonics reconstructions on a regional $(>100 \mathrm{~km})$ scale have grown increasingly tractable as data coverage approaches the coverage of the sedimentary record.

Lacking sufficient Macrostrat coverage to repeat this analysis elsewhere, the western North America sample coverage emphasizes the utility of a terrestrial stable isotope database for the Cenozoic. With this expansive, multi-proxy coverage, studies that interpret spatial gradients in isotope ratios (Cassel and others, 2018; Chamberlain and others, 2012; Fan and others, 2014a; Mulch and others, 2006; Sjostrom and others, 2006), differences in isotope ratios between proxies (Tabor \& Montañez 2005; Stern and others, 1997; Poage \& Chamberlain 2002; Tabor and others, 2002), or other dimensions beyond the outcrop scale are becoming easier and more common. We anticipate that the database presented here will further contribute to this ongoing work to understand data spatially and across proxies.

\section{DATA STRUCTURE}

\subsection{Balancing data grouping and data integrity}

One challenge in synthesizing data is making data easy to extract based on a wide range of dimensions without grouping the data so broadly that useful information is lost. For example, it is not particularly helpful to group all paleosol data by paleosol depth horizon because the depth horizon is not commonly reported. However, it is important to keep the depth horizon information available for those that find it useful for modeling purposes (Caves and others, 2016; Gao and others, 2021). To address this problem, we constrain the inputs for each data entry column to one of three input categories - free, flexible, or fixed inputs. These three input types are designed for efficient data queries (with flexible and fixed inputs) and minimal data loss or compromise relative to the original publication (with free inputs).

Free input columns are those that accept any values (numeric, character, date, etc) usually related to notes or descriptions about the data, locality, sample, or sedimentary interpretation. For example, a free input column might note the specific name of a sample site, how the age model was constructed, or the accuracy of the listed coordinates. Due to the flexibility of free input columns, they are not very useful for querying data but are useful for contextualizing and understanding data once it is selected.

Flexible input columns require a specific type of input (like a numeric or character) but the value of the input is not constrained. We use two types of flexible input columns - alphanumeric and numeric flexible inputs. Alphanumeric 
flexible inputs are publication references or codes that identify entities like a locality or sample. These inputs are flexible, rather than free, because they contain input restrictions such as following a reference format or disallowing spaces or certain characters. Numeric flexible inputs (restricted to numbers) include columns such as the age of the sample or its isotopic ratio. Numeric flexible input columns are useful for querying data based on quantitative characteristics such as geographic range (latitude and longitude) or age range (e.g. the Eocene, 56-34 Ma).

Fixed inputs columns allow only a fixed set of input values. Fixed input columns are used for broad grouping of data types by defining the sample material and its basic lithology or fossil source. They also include columns that accept binary values (yes or no) that are useful for data filtering (for example, to remove duplicated values that were published in one paper and compiled in a later paper). Fixed input columns are designed for querying qualitative data characteristics, such as data from a specific mineral or type of deposit (e.g. paleosol versus lacustrine carbonate). Together, these three column input types are designed to meet a range of data query and post-processing goals while minimizing the amount of information that is lost or condensed.

Table 1. Papers included in the database. The data entries column refers to the number of unique sample IDs.

\begin{tabular}{|c|c|c|c|}
\hline & Reference & Sample type(s) & Data entries \\
\hline 1 & Abels and others, (2012) & inorganic carbonate (paleosol + fluvial) & 288 \\
\hline 2 & Abruzzese and others, (2005) & other, inorganic carbonate lacustrine & 96 \\
\hline 3 & Alçiçek \& Jiménez-Moreno (2013) & inorganic carbonate (paleosol + fluvial), inorganic carbonate lacustrine & 38 \\
\hline 4 & Alonso-Zarza \& Arenas (2004) & inorganic carbonate (paleosol + fluvial) & 29 \\
\hline 5 & Amundson and others, (1996) & inorganic carbonate (paleosol + fluvial) & 51 \\
\hline 6 & Anadón and others, (2015) & shell & 101 \\
\hline 7 & Andrews and others, (1997) & $\begin{array}{l}\text { other, inorganic carbonate (paleosol + fluvial), shell, inorganic carbon- } \\
\text { ate lacustrine }\end{array}$ & 78 \\
\hline 8 & Arehart \& O’Neil (1993) & high temperature & 16 \\
\hline 9 & Arenas and others, (1997) & inorganic carbonate lacustrine & 137 \\
\hline 10 & Arppe \& Karhu (2010) & mammal & 120 \\
\hline 11 & Baczynski and others, (2013) & inorganic carbonate (paleosol + fluvial), organic & 330 \\
\hline 12 & Bajnóczi and others, (2006) & inorganic carbonate (paleosol + fluvial) & 32 \\
\hline 13 & Ballato and others, (2010) & inorganic carbonate (paleosol + fluvial), inorganic carbonate lacustrine & 181 \\
\hline 14 & Bataille and others, (2016) & inorganic carbonate (paleosol + fluvial) & 341 \\
\hline 15 & Bentaleb and others, (2006) & mammal & 20 \\
\hline 16 & Bershaw and others, (2012) & inorganic carbonate (paleosol + fluvial) & 13 \\
\hline 17 & Bershaw and others, (2019) & volcanic glass & 13 \\
\hline 18 & Bill and others, (2018) & phyllosilicate & 57 \\
\hline 19 & Boardman \& Secord (2013) & mammal & 114 \\
\hline 20 & Bougeois and others, (2018) & $\begin{array}{l}\text { inorganic carbonate (paleosol }+ \text { fluvial), other, inorganic carbonate } \\
\text { lacustrine }\end{array}$ & 91 \\
\hline 21 & Bowen \& Beitler Bowen (2008) & inorganic carbonate (paleosol + fluvial) & 47 \\
\hline 22 & Bowen and others, (2001) & inorganic carbonate (paleosol + fluvial) & 354 \\
\hline 23 & Bowen and others, (2005) & inorganic carbonate (paleosol + fluvial) & 145 \\
\hline 24 & Bowen and others, (2014) & inorganic carbonate (paleosol + fluvial) & 290 \\
\hline 25 & Burgener and others, (2019) & inorganic carbonate (paleosol + fluvial) & 53 \\
\hline 26 & Campani and others, (2012) & inorganic carbonate (paleosol + fluvial), phyllosilicate & 209 \\
\hline 27 & Carroll and others, (2008) & inorganic carbonate lacustrine & 136 \\
\hline 28 & Cassel and others, (2009) & volcanic glass & 32 \\
\hline 29 & Cassel and others, (2012) & volcanic glass & 18 \\
\hline 30 & Cassel and others, (2014) & volcanic glass & 22 \\
\hline 31 & Cassel and others, (2018) & volcanic glass & 85 \\
\hline 32 & Caves and others, (2014) & inorganic carbonate (paleosol + fluvial) & 122 \\
\hline
\end{tabular}


Table 1. Papers included in the database. The data entries column refers to the number of unique sample IDs.

\begin{tabular}{|c|c|c|c|}
\hline & Reference & Sample type(s) & Data entries \\
\hline 33 & Caves and others, (2016) & inorganic carbonate (paleosol + fluvial), inorganic carbonate lacustrine & 94 \\
\hline 34 & Caves (2017) & inorganic carbonate (paleosol + fluvial) & 82 \\
\hline 35 & Chamberlain and others, (2012) & $\begin{array}{l}\text { inorganic carbonate (paleosol }+ \text { fluvial), inorganic carbonate lacus- } \\
\text { trine, phyllosilicate }\end{array}$ & 674 \\
\hline 36 & Chamberlain and others, (2020) & high temperature & 45 \\
\hline 37 & Charreau and others, (2012) & inorganic carbonate (paleosol + fluvial) & 216 \\
\hline 38 & Clyde and others, (2010) & inorganic carbonate (paleosol + fluvial) & 78 \\
\hline 39 & Criss \& Taylor (1983) & high temperature & 1 \\
\hline 40 & Crowley and others, (2008) & mammal & 147 \\
\hline 41 & Csonka and others, (2020) & inorganic carbonate (paleosol + fluvial) & 43 \\
\hline 42 & Currie and others, (2005) & inorganic carbonate (paleosol + fluvial) & 7 \\
\hline 43 & Currie and others, (2016) & inorganic carbonate (paleosol + fluvial) & 12 \\
\hline 44 & Cyr and others, (2005) & inorganic carbonate lacustrine & 39 \\
\hline 45 & Davis and others, (2008) & inorganic carbonate lacustrine & 205 \\
\hline 46 & Davis and others, (2009a) & inorganic carbonate lacustrine & 184 \\
\hline 47 & Davis and others, (2009b) & inorganic carbonate lacustrine & 209 \\
\hline 48 & Dean and others, (2015) & inorganic carbonate lacustrine & 1524 \\
\hline 49 & DeCelles and others, (2007) & inorganic carbonate (paleosol + fluvial) & 31 \\
\hline 50 & DeCelles and others, (2011) & inorganic carbonate (paleosol + fluvial) & 15 \\
\hline 51 & Dettman \& Lohmann (2000) & shell & 618 \\
\hline 52 & Dettman and others, (2001) & shell, mammal & 401 \\
\hline 53 & Dettman and others, (2003) & inorganic carbonate (paleosol + fluvial), inorganic carbonate lacustrine & 141 \\
\hline 54 & Ding \& Yang (2000) & inorganic carbonate (paleosol + fluvial) & 220 \\
\hline 55 & Ding and others, (2014) & inorganic carbonate lacustrine, inorganic carbonate (paleosol + fluvial) & 56 \\
\hline 56 & Doebbert and others, (2010) & inorganic carbonate lacustrine & 212 \\
\hline 57 & Domingo and others, (2013) & mammal & 298 \\
\hline 58 & Dong and others, (2018) & inorganic carbonate (paleosol + fluvial) & 384 \\
\hline 59 & Eren (2011) & inorganic carbonate (paleosol + fluvial) & 24 \\
\hline 60 & Fan \& Dettman (2009) & shell & 981 \\
\hline 61 & Fan and others, (2011) & inorganic carbonate (paleosol + fluvial) & 32 \\
\hline 62 & Fan and others, (2014b) & $\begin{array}{l}\text { inorganic carbonate lacustrine, inorganic carbonate (paleosol }+\mathrm{flu}- \\
\text { vial), shell }\end{array}$ & 25 \\
\hline 63 & Fan and others, (2014a) & volcanic glass & 72 \\
\hline 64 & Fan and others, (2017) & inorganic carbonate (paleosol + fluvial), shell & 204 \\
\hline 65 & Fan and others, (2018) & inorganic carbonate (paleosol + fluvial) & 108 \\
\hline 66 & Fan and others, (2021) & shell, inorganic carbonate (paleosol + fluvial) & 426 \\
\hline 67 & Foreman and others, (2011) & $\begin{array}{l}\text { shell, inorganic carbonate (paleosol + fluvial), inorganic carbonate la- } \\
\text { custrine, fish }\end{array}$ & 9 \\
\hline 68 & Foreman and others, (2015) & inorganic carbonate (paleosol + fluvial), shell & 94 \\
\hline 69 & Fox \& Koch (2003) & inorganic carbonate (paleosol + fluvial) & 274 \\
\hline 70 & Fox \& Koch (2004) & inorganic carbonate (paleosol + fluvial) & 28 \\
\hline 71 & Fox and others, (2012) & inorganic carbonate (paleosol + fluvial) & 194 \\
\hline 72 & Fricke \& Wing (2004) & fish, mammal & 39 \\
\hline 73 & Fricke and others, (1998) & mammal, fish & 210 \\
\hline 74 & Fricke and others, (2008) & fish, reptile, shell, inorganic carbonate (paleosol + fluvial) & 157 \\
\hline 75 & Fricke and others, (2010) & inorganic carbonate (paleosol + fluvial), shell & 68 \\
\hline
\end{tabular}


Table 1. Papers included in the database. The data entries column refers to the number of unique sample IDs.

\begin{tabular}{|c|c|c|c|}
\hline & Reference & Sample type(s) & Data entries \\
\hline 76 & Fricke (2003) & mammal & 47 \\
\hline 77 & Gallant and others, (2014) & inorganic carbonate (paleosol + fluvial) & 26 \\
\hline 78 & Garzione and others, (2000) & inorganic carbonate (paleosol + fluvial) & 34 \\
\hline 79 & Gébelin and others, (2012) & inorganic carbonate lacustrine, high temperature & 68 \\
\hline 80 & Genty and others, (2003) & other & 300 \\
\hline 81 & Ghosh and others, (2004) & inorganic carbonate (paleosol + fluvial) & 64 \\
\hline 82 & Godfrey and others, (2018) & inorganic carbonate (paleosol + fluvial) & 167 \\
\hline 83 & Harris and others, (2020) & mammal & 227 \\
\hline 84 & Harzhauser and others, (2007) & shell & 117 \\
\hline 85 & Harzhauser and others, (2012) & shell & 164 \\
\hline 86 & Heitmann and others, (2017) & inorganic carbonate (paleosol + fluvial) & 145 \\
\hline 87 & Hellwig and others, (2018) & inorganic carbonate (paleosol + fluvial) & 78 \\
\hline 88 & Hofman-Kamińska and others, (2018) & mammal & 116 \\
\hline 89 & Hoke and others, (2014) & inorganic carbonate (paleosol + fluvial) & 118 \\
\hline 90 & Honegger and others, (2020) & inorganic carbonate (paleosol + fluvial) & 149 \\
\hline 91 & Horton \& Chamberlain (2006) & inorganic carbonate lacustrine, phyllosilicate & 213 \\
\hline 92 & Horton and others, (2004) & inorganic carbonate lacustrine, other, phyllosilicate & 134 \\
\hline 93 & Hough and others, (2011) & inorganic carbonate (paleosol + fluvial), inorganic carbonate lacustrine & 218 \\
\hline 94 & Hren and others, (2010) & organic & 20 \\
\hline 95 & Huntington and others, (2009) & inorganic carbonate lacustrine & 7 \\
\hline 96 & Huntington and others, (2010) & inorganic carbonate lacustrine & 70 \\
\hline 97 & Huntington and others, (2011) & shell, inorganic carbonate (paleosol + fluvial) & 11 \\
\hline 98 & Huyghe and others, (2017) & 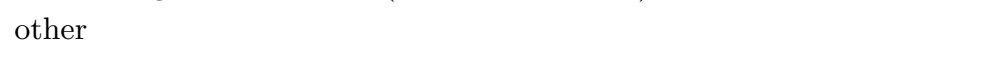 & 28 \\
\hline 99 & Hyland \& Sheldon (2013) & inorganic carbonate (paleosol + fluvial), organic & 58 \\
\hline 100 & Hyland and others, (2013) & inorganic carbonate (paleosol + fluvial), organic & 32 \\
\hline 101 & Ibarra and others, (2021) & other, inorganic carbonate lacustrine & 23 \\
\hline 102 & Ingalls and others, (2018) & inorganic carbonate (paleosol + fluvial), inorganic carbonate lacustrine & 72 \\
\hline 103 & Jensen and others, (2020) & mammal & 41 \\
\hline 104 & Jiang (2002) & inorganic carbonate (paleosol + fluvial) & 73 \\
\hline 105 & Kaakinen and others, (2006) & inorganic carbonate (paleosol + fluvial) & 96 \\
\hline 106 & Kelson and others, (2018) & inorganic carbonate (paleosol + fluvial) & 35 \\
\hline 107 & Kent-Corson and others, (2006) & inorganic carbonate (paleosol + fluvial) & 183 \\
\hline 108 & Kent-Corson and others, (2009) & $\begin{array}{l}\text { inorganic carbonate (paleosol }+ \text { fluvial), inorganic carbonate lacus- } \\
\text { trine, other }\end{array}$ & 1383 \\
\hline 109 & Kent-Corson and others, (2010) & inorganic carbonate (paleosol + fluvial) & 91 \\
\hline 110 & Kent-Corson and others, (2013) & inorganic carbonate (paleosol + fluvial), inorganic carbonate lacustrine & 134 \\
\hline 111 & Kluge \& Affek (2012) & other & 27 \\
\hline 112 & Koch and others, (1995) & inorganic carbonate (paleosol + fluvial), mammal & 217 \\
\hline 113 & Koch and others, (2003) & inorganic carbonate (paleosol + fluvial), organic & 460 \\
\hline 114 & Kocsis and others, (2014) & mammal & 219 \\
\hline 115 & Kohn \& Law (2006) & mammal, fish & 337 \\
\hline 116 & Kohn and others, (2002) & mammal & 207 \\
\hline 117 & Kovács and others, (2012) & mammal & 36 \\
\hline 118 & Kovács and others, (2015) & mammal & 57 \\
\hline 119 & Kovda and others, (2008) & inorganic carbonate (paleosol + fluvial) & 44 \\
\hline 120 & Küçükuysal \& Kapur (2014) & inorganic carbonate (paleosol + fluvial) & 11 \\
\hline
\end{tabular}


Table 1. Papers included in the database. The data entries column refers to the number of unique sample IDs.

\begin{tabular}{|c|c|c|c|}
\hline & Reference & Sample type(s) & Data entries \\
\hline 121 & Kukla and others, (2021b) & phyllosilicate & 84 \\
\hline 122 & Lacroix \& Niemi (2019) & inorganic carbonate lacustrine & 32 \\
\hline 123 & Latorre and others, (1997) & mammal & 46 \\
\hline 124 & Leary and others, (2017) & inorganic carbonate (paleosol + fluvial) & 43 \\
\hline 125 & Lechler \& Niemi (2011) & inorganic carbonate lacustrine & 4 \\
\hline 126 & Leone and others, (2000) & inorganic carbonate (paleosol + fluvial), shell & 126 \\
\hline 127 & Li and others, (2015) & inorganic carbonate lacustrine, shell & 50 \\
\hline 128 & Li and others, (2016a) & inorganic carbonate (paleosol + fluvial) & 288 \\
\hline 129 & Li and others, (2016b) & inorganic carbonate (paleosol + fluvial), inorganic carbonate lacustrine & 128 \\
\hline 130 & Li and others, (2021) & volcanic glass & 60 \\
\hline 131 & Licht and others, (2014) & mammal, shell & 268 \\
\hline 132 & Licht and others, (2017a) & inorganic carbonate (paleosol + fluvial) & 66 \\
\hline 133 & Licht and others, (2017b) & $\begin{array}{l}\text { inorganic carbonate (paleosol }+ \text { fluvial), inorganic carbonate lacus- } \\
\text { trine, other }\end{array}$ & 46 \\
\hline 134 & Licht and others, (2020) & inorganic carbonate (paleosol + fluvial), organic & 438 \\
\hline 135 & Liu and others, (2014) & inorganic carbonate (paleosol + fluvial), inorganic carbonate lacustrine & 1804 \\
\hline 136 & Lüdecke and others, (2013) & inorganic carbonate lacustrine & 230 \\
\hline 137 & Lukens and others, (2017) & inorganic carbonate (paleosol + fluvial), other & 69 \\
\hline 138 & Macaulay and others, (2016) & inorganic carbonate (paleosol + fluvial) & 35 \\
\hline 139 & Mack \& Cole (2005) & inorganic carbonate (paleosol + fluvial) & 5 \\
\hline 140 & Mack and others, (1994) & inorganic carbonate (paleosol + fluvial) & 31 \\
\hline 141 & Matson \& Fox (2010) & mammal & 181 \\
\hline 142 & Matson and others, (2012) & organic, inorganic carbonate (paleosol + fluvial) & 66 \\
\hline 143 & McFadden and others, (2015) & high temperature & 10 \\
\hline 144 & McLean \& Bershaw (2021) & inorganic carbonate (paleosol + fluvial) & 17 \\
\hline 145 & Meijers and others, (2016) & inorganic carbonate lacustrine & 162 \\
\hline 146 & Meijers and others, (2018) & inorganic carbonate lacustrine & 101 \\
\hline 147 & Methner and others, (2015) & high temperature, other & 85 \\
\hline 148 & Methner and others, (2016b) & inorganic carbonate (paleosol + fluvial) & 123 \\
\hline 149 & Methner and others, (2016a) & inorganic carbonate (paleosol + fluvial), inorganic carbonate lacustrine & 161 \\
\hline 150 & Methner and others, (2020) & inorganic carbonate (paleosol + fluvial) & 114 \\
\hline 151 & Mix \& Chamberlain (2014) & phyllosilicate & 231 \\
\hline 152 & Mix and others, (2013) & inorganic carbonate (paleosol + fluvial) & 55 \\
\hline 153 & Mix and others, (2016) & phyllosilicate & 34 \\
\hline 154 & Mix and others, (2019) & $\begin{array}{l}\text { inorganic carbonate (paleosol }+ \text { fluvial), inorganic carbonate lacus- } \\
\text { trine, phyllosilicate }\end{array}$ & 165 \\
\hline 155 & Mulch and others, (2006) & phyllosilicate & 34 \\
\hline 156 & Mulch and others, (2007) & high temperature, other & 39 \\
\hline 157 & Mulch and others, (2008) & volcanic glass & 83 \\
\hline 158 & Mulch and others, (2015) & $\begin{array}{l}\text { inorganic carbonate (paleosol }+ \text { fluvial), inorganic carbonate lacus- } \\
\text { trine, phyllosilicate }\end{array}$ & 72 \\
\hline 159 & Mullin (2010) & inorganic carbonate (paleosol + fluvial) & 31 \\
\hline 160 & Nehme and others, (2020) & other & 4 \\
\hline 161 & Ortiz and others, (2006) & shell & 424 \\
\hline 162 & Page and others, (2019) & inorganic carbonate (paleosol + fluvial) & 20 \\
\hline 163 & Passey and others, (2009) & inorganic carbonate (paleosol + fluvial), mammal & 293 \\
\hline
\end{tabular}


Table 1. Papers included in the database. The data entries column refers to the number of unique sample IDs.

\begin{tabular}{|c|c|c|c|}
\hline & Reference & Sample type(s) & Data entries \\
\hline 164 & Peryam and others, (2011) & inorganic carbonate (paleosol + fluvial) & 47 \\
\hline 165 & Poage \& Chamberlain (2002) & $\begin{array}{l}\text { inorganic carbonate (paleosol + fluvial), phyllosilicate, inorganic car- } \\
\text { bonate lacustrine }\end{array}$ & 40 \\
\hline 166 & Poulson \& John (2003) & inorganic carbonate lacustrine & 27 \\
\hline 167 & Quade and others, (1989) & inorganic carbonate (paleosol + fluvial) & 111 \\
\hline 168 & Quade and others, (1994) & inorganic carbonate (paleosol + fluvial), organic, mammal & 60 \\
\hline 169 & Quade and others, (1995) & inorganic carbonate (paleosol + fluvial) & 48 \\
\hline 170 & Retallack and others, (2004) & inorganic carbonate (paleosol + fluvial) & 355 \\
\hline 171 & Ring and others, (2020) & mammal & 41 \\
\hline 172 & Rothe and others, (1974) & shell, other & 76 \\
\hline 173 & Rowe and others, (2020) & other & 421 \\
\hline 174 & Rowley \& Currie (2006) & inorganic carbonate lacustrine, inorganic carbonate (paleosol + fluvial) & 3 \\
\hline 175 & San Jose and others, (2020) & $\begin{array}{l}\text { inorganic carbonate (paleosol }+ \text { fluvial), other, inorganic carbonate } \\
\text { lacustrine, shell }\end{array}$ & 274 \\
\hline 176 & Sanyal and others, (2005) & inorganic carbonate (paleosol + fluvial) & 64 \\
\hline 177 & Saylor and others, (2009) & inorganic carbonate lacustrine & 252 \\
\hline 178 & Scherler and others, (2014) & mammal & 92 \\
\hline 179 & Schlunegger and others, (2007) & inorganic carbonate (paleosol + fluvial) & 54 \\
\hline 180 & Schwartz and others, (2019) & inorganic carbonate lacustrine, inorganic carbonate (paleosol + fluvial) & 74 \\
\hline 181 & Sjostrom and others, (2006) & phyllosilicate & 62 \\
\hline 182 & Smith and others, (1993) & inorganic carbonate (paleosol + fluvial) & 52 \\
\hline 183 & Smith and others, (2017) & volcanic glass & 14 \\
\hline 184 & Spencer and others, (1996) & shell & 2 \\
\hline 185 & Stern and others, (1997) & phyllosilicate, inorganic carbonate (paleosol + fluvial) & 68 \\
\hline 186 & Sun and others, (2017) & inorganic carbonate (paleosol + fluvial), inorganic carbonate lacustrine & 176 \\
\hline 187 & Super $(2010)$ & phyllosilicate & 18 \\
\hline 188 & Takeuchi \& Larson (2005) & phyllosilicate & 17 \\
\hline 189 & Takeuchi and others, (2010) & inorganic carbonate (paleosol + fluvial) & 117 \\
\hline 190 & Takeuchi (2007) & phyllosilicate & 55 \\
\hline 191 & Tang and others, (2017) & inorganic carbonate (paleosol + fluvial) & 28 \\
\hline 192 & Ting and others, (2003) & inorganic carbonate (paleosol + fluvial) & 59 \\
\hline 193 & Torres \& Gaines (2013) & inorganic carbonate (paleosol + fluvial) & 25 \\
\hline 194 & Tütken and others, (2008) & mammal & 49 \\
\hline 195 & Vasilyan \& Carnevale (2013) & inorganic carbonate (paleosol + fluvial) & 24 \\
\hline 196 & Vögeli and others, (2017) & inorganic carbonate (paleosol + fluvial) & 48 \\
\hline 197 & Wang \& Deng (2005) & mammal & 126 \\
\hline 198 & Wang and others, (1993) & $\begin{array}{l}\text { inorganic carbonate (paleosol }+ \text { fluvial), inorganic carbonate lacus- } \\
\text { trine, mammal }\end{array}$ & 59 \\
\hline 199 & Wang and others, (1996) & inorganic carbonate (paleosol + fluvial) & 3 \\
\hline 200 & Wei and others, (2016) & inorganic carbonate lacustrine & 58 \\
\hline 201 & White \& Schiebout (2008) & inorganic carbonate (paleosol + fluvial) & 123 \\
\hline 202 & White and others, (2001) & inorganic carbonate (paleosol + fluvial) & 11 \\
\hline 203 & White and others, (2017) & phyllosilicate & 9 \\
\hline 204 & Winnick and others, (2013) & inorganic carbonate (paleosol + fluvial) & 106 \\
\hline 205 & $\mathrm{Xu}$ and others, (2013) & inorganic carbonate (paleosol + fluvial), inorganic carbonate lacustrine & 35 \\
\hline 206 & $\mathrm{Xu}$ and others, $(2015)$ & inorganic carbonate (paleosol + fluvial) & 37 \\
\hline
\end{tabular}


Table 1. Papers included in the database. The data entries column refers to the number of unique sample IDs.

\begin{tabular}{llll}
\hline Reference & Sample type(s) & Data entries \\
\hline 207 Xu and others, (2016) & inorganic carbonate (paleosol + fluvial), inorganic carbonate lacustrine & 11 \\
208 & Zamarreno and others, (1997) & inorganic carbonate (paleosol + fluvial), inorganic carbonate lacustrine & 111 \\
209 & Zanazzi and others, (2007) & mammal & 548 \\
210 & Zanazzi and others, (2015) & mammal & 19 \\
211 Zhuang and others, (2011) & inorganic carbonate (paleosol + fluvial), inorganic carbonate lacustrine & 107 \\
\hline
\end{tabular}

\subsection{Data fields hierarchy}

Any given stable isotope value rests on a hierarchy of information designed to simplify data querying and postprocessing steps (Fig. 3). The basic unit of this structure is the publication (or a dataset ID in cases where data is unpublished such as publicly available $\mathrm{MS}$ and $\mathrm{PhD}$ theses). While a more basic unit would be a given sample basin or locality, we use the publication because not all samples are linked to a given basin (e.g. altered igneous or metamorphic rock) and the publication unit simplifies the data entry step, especially in cases where the sampling basin is not reported and must be independently determined.

Within every publication, we define at least one section ID. Section IDs are flexible alphanumeric inputs that separate groups of samples by space and geologic time. Often, they are defined based on how the original publication grouped data. When no groupings are available, we define a single section ID as a group of data from a continuous or nearcontinuous sedimentary package, sampled within an areal range of tens of kilometers or less. This definition is not rigid (i.e. there is no strict geographic or temporal cut-off between section IDs) because we want to account for cases where nearby sections in space and time show distinct results. For example, if two outcrops of the same age a few kilometers apart have distinct isotope ratios, we will preserve this distinction by assigning separate section IDs, despite their close spatial and temporal proximity. Therefore, users that wish to group data by section ID do not lose this information.

After the section ID, the next delineations are the sample coordinates, sample grouping, and sample ID. Coordinates (latitude $[-90,90]$ and longitude $[-180,180)$ ) are flexible numeric inputs reported in decimal degrees to the resolution of the original paper unless otherwise noted. In cases where the coordinates are not reported, we make an estimate based on the available information (often a map figure or survey systems such as the section, township and range survey location previously used in the United States) and note our approximation. The sample type and sample material are flexible alphanumeric inputs. There are two sample type columns recording similar information in more general and specific terms. The basic sample type defines a given sample based on its lithological, mineralogical, or fossil origin (e.g. "phyllosilicate" or "shell") and the more specific sample type distinguishes between sub-categories (e.g. "altered ash" or "mollusc"). The sample material denotes the mineral or material measured (e.g. "smectite" or "aragonite"). Finally, the sample ID is a flexible alphanumeric identification code assigned by the original paper or, when none is available, generated by us. We deviate from the sample ID defined by the original paper if multiple sample types are measured for a given sample ID. In this case, we append a suffix to the sample ID that distinguishes the sample type (such as "XXorg" and "XXcarb" for organic and carbonate carbon measurements of the same hand sample).

The last two delineations, the replicate ID (flexible alphanumeric) and isotope ratio (flexible numeric), refer to individual measurements. The replicate ID distinguishes individual measurements of a single sample and is often defined based on the sample ID and some suffix (such as "1, 2, 3..."). In cases where the sample was not replicated, the replicate and sample IDs are identical or replicate IDs are left blank. In some cases, only the average isotope ratio of multiple samples is reported (and individual measurements are not available), and we enter the isotope ratio as if it were a single measurement and note that the value reflects the average of multiple measurements. Finally, the isotope ratio is the last level of the hierarchy, and is a numeric value assigned to one of 5 columns $\left(\delta^{18} O, \delta^{13} C, \delta D, \Delta_{47}\right.$, $\left.\Delta^{17} O\right)$. All data in a given column are reported relative to the same isotope standard.

All column names are grouped by their data input type (free, flexible, or fixed) and described in Table 2. Aside from the hierarchical inputs outlined in Figure 3, other columns provide sample-specific information like the outcrop height and age uncertainty as well as notes about the data or decisions made during data entry. For a full list of the column input restrictions by column, see the database user guide in the Supplementary Information. 


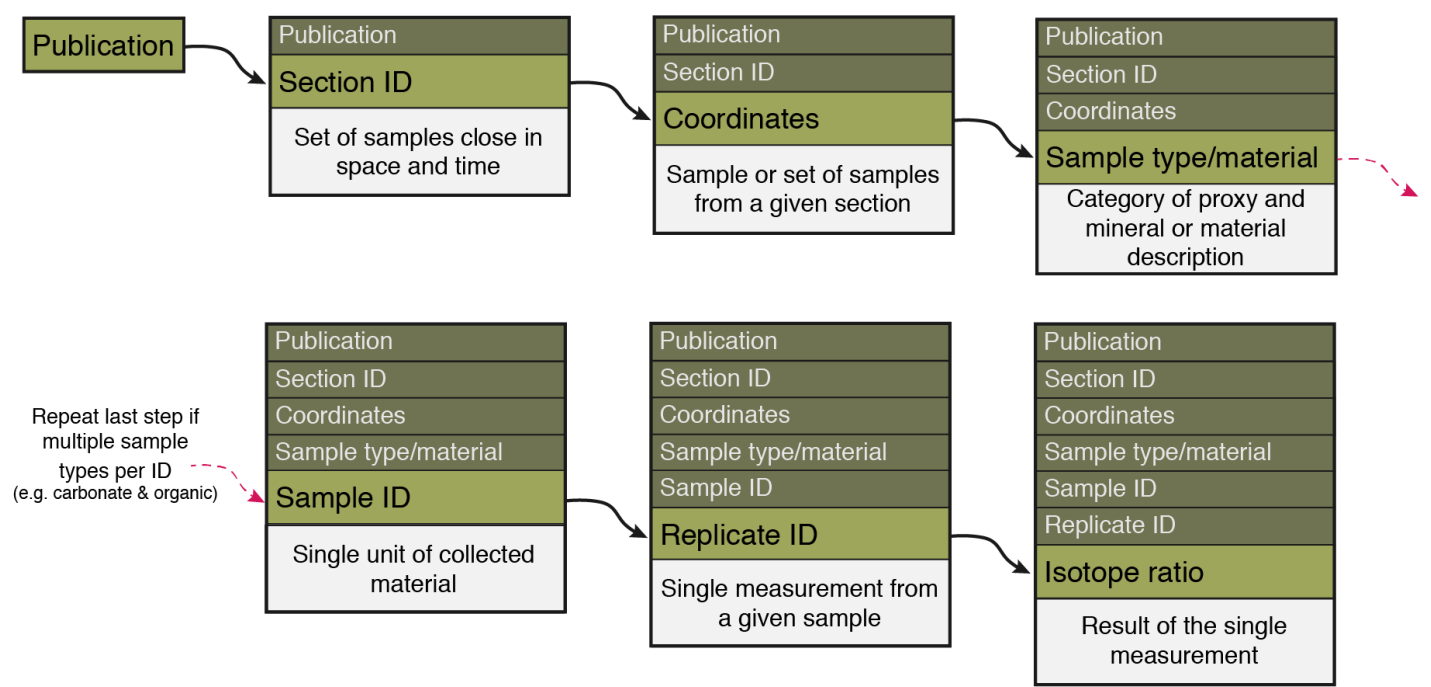

Figure 3. Illustrated data hierarchy for flexible queries. Red arrow marks duplicating Sample IDs assigned by the original author if the same sample is run for more than one isotope proxy system.

Table 2. Name and description of all data entry columns in the database.

\begin{tabular}{|c|c|c|c|}
\hline $\begin{array}{l}\text { Data entry } \\
\text { category }\end{array}$ & Column header & Description & Example input \\
\hline Fixed & Sample_type_basic & General designation of sample type & $\begin{array}{l}\text { inorganic } \\
\text { lacustrine }\end{array}$ \\
\hline Fixed & Sample_type & Lithologic or fossil origin of sample & Altered ash \\
\hline Fixed & Sample_material & Mineral or sample material measured & kaolinite \\
\hline Fixed & Previously_published & $\begin{array}{l}\text { Yes }(\mathrm{Y}) \text { or no }(\mathrm{N}) \text { denoting if the measurement was also } \\
\text { published in an earlier paper (useful for papers that present } \\
\text { compilations) }\end{array}$ & $\mathrm{N}$ \\
\hline Fixed & Event & $\begin{array}{l}\text { Name of climate or other event covered by the section or a set } \\
\text { of samples }\end{array}$ & PETM \\
\hline Fixed & Event_excursion? & $\begin{array}{l}\text { Yes }(\mathrm{Y}) \text { or no }(\mathrm{N}) \text { denoting if the sample occurs during a tran- } \\
\text { sient excursion (for filtering with long-term data) }\end{array}$ & $\mathrm{Y}$ \\
\hline Fixed & Author_upload & $\begin{array}{l}\text { Yes }(\mathrm{Y}) \text { if data was uploaded by the author or person generating } \\
\text { the new data, no }(\mathrm{N}) \text { if uploaded by PATCH Lab curators. }\end{array}$ & $\mathrm{N}$ \\
\hline $\begin{array}{l}\text { Flexible } \\
\text { (alphanu- } \\
\text { meric) }\end{array}$ & Reference & $\begin{array}{l}\text { Original publication or data entry contact (for unpublished } \\
\text { data) }\end{array}$ & Abels et al., 2012 \\
\hline $\begin{array}{l}\text { Flexible } \\
\text { (alphanu- } \\
\text { meric) }\end{array}$ & Reference_ID & Unique alphanumeric code for the reference & ABELS12 \\
\hline $\begin{array}{l}\text { Flexible } \\
\text { (alphanu- } \\
\text { meric) }\end{array}$ & Section_ID & Unique alphanumeric code for the section site & ABELS12_UDC \\
\hline $\begin{array}{l}\text { Flexible } \\
\text { (alphanu- } \\
\text { meric) }\end{array}$ & Sample_ID & Unique alphanumeric code for the sample & UDC-1 \\
\hline $\begin{array}{l}\text { Flexible } \\
\text { (alphanu- } \\
\text { meric) }\end{array}$ & Replicate_ID & Unique alphanumeric code for replicated measurement & UDC-1a \\
\hline
\end{tabular}


Table 2. Name and description of all data entry columns in the database.

\begin{tabular}{|c|c|c|c|}
\hline $\begin{array}{l}\text { Data entry } \\
\text { category }\end{array}$ & Column header & Description & Example input \\
\hline $\begin{array}{l}\text { Flexible } \\
\text { (alphanu- } \\
\text { meric) }\end{array}$ & PrevPublished_Ref & $\begin{array}{l}\text { Reference for the paper where data was originally published (if } \\
\text { Previously_published }=\mathrm{Y} \text {, otherwise blank) }\end{array}$ & \\
\hline $\begin{array}{l}\text { Flexible } \\
\text { (numeric) }\end{array}$ & Latitude & Sample latitude in decimal degrees & 44.2 \\
\hline $\begin{array}{l}\text { Flexible } \\
\text { (numeric) }\end{array}$ & Longitude & Sample longitude in decimal degrees (range $-180,180$ ) & -113.5 \\
\hline $\begin{array}{l}\text { Flexible } \\
\text { (numeric) }\end{array}$ & Height_m & Height (or depth, if core) of sample in meters & 80 \\
\hline $\begin{array}{l}\text { Flexible } \\
\text { (numeric) }\end{array}$ & Age_Ma & Assigned sample age in million years ago (Ma) & 55 \\
\hline $\begin{array}{l}\text { Flexible } \\
\text { (numeric) }\end{array}$ & Top_age_Ma & Youngest age uncertainty bound (stratigraphic top) & 54 \\
\hline $\begin{array}{l}\text { Flexible } \\
\text { (numeric) }\end{array}$ & Bottom_age_Ma & Oldest age uncertainty bound (stratigraphic bottom) & 58 \\
\hline $\begin{array}{l}\text { Flexible } \\
\text { (numeric) }\end{array}$ & d18O_smow & Oxygen isotope measurement (permille VSMOW) & 20 \\
\hline $\begin{array}{l}\text { Flexible } \\
\text { (numeric) }\end{array}$ & d13C_pdb & Carbon isotope measurement (permille VPDB) & -4 \\
\hline $\begin{array}{l}\text { Flexible } \\
\text { (numeric) }\end{array}$ & dD_smow & Hydrogen isotope measurement (permille VSMOW) & -120 \\
\hline $\begin{array}{l}\text { Flexible } \\
\text { (numeric) }\end{array}$ & D17O_permille & Triple-oxygen isotope measurement & -0.20 \\
\hline $\begin{array}{l}\text { Flexible } \\
\text { (numeric) }\end{array}$ & D17O_lambda & Triple-oxygen isotope slope for calculation & 0.528 \\
\hline $\begin{array}{l}\text { Flexible } \\
\text { (numeric) }\end{array}$ & D47_permille & Clumped isotope measurement & 0.500 \\
\hline $\begin{array}{l}\text { Flexible } \\
\text { (numeric) }\end{array}$ & d18Oprecip_smow & Reported composition of meteoric water & -10 \\
\hline $\begin{array}{l}\text { Flexible } \\
\text { (numeric) }\end{array}$ & dDprecip_smow & Reported composition of meteoric water & -70 \\
\hline $\begin{array}{l}\text { Flexible } \\
\text { (numeric) }\end{array}$ & Other_data_value_X & $\begin{array}{l}\text { Value of an additional data type relevant to isotope data ( } 3 \\
\text { columns where } \mathrm{X}=1,2 \text {, or } 3 \text { ) }\end{array}$ & 65 \\
\hline Free & Other_data_type_X & $\begin{array}{l}\text { Type of additional data noted in "Other_data_value_X" ( } 3 \\
\text { columns where } \mathrm{X}=1,2 \text {, or } 3)\end{array}$ & Percent carbonate \\
\hline Free & Sample_notes & Most relevant additional information about sample & Carbonate root cast \\
\hline Free & Notes_1 & Relevant notes about sample or section & Upper Deer Creek section \\
\hline Free & Notes_2 & Relevant notes about sample or section & Bighorn Basin \\
\hline Free & Data_entry_notes & Details about entry to database & $\begin{array}{l}\text { Locations approximate } \\
\text { using map in Fig. } 1\end{array}$ \\
\hline Free & $\begin{array}{l}\text { Published_wateriso } \\
\text { interpretation }\end{array}$ & $\begin{array}{l}\text { Interpreted driver of water isotope value (blank if meteoric or } \\
\text { primary fluid) }\end{array}$ & evaporative \\
\hline Free & $\begin{array}{l}\text { Published_carboniso } \\
\text { _interpretation }\end{array}$ & Interpreted driver of carbon isotope value (blank if primary) & $\begin{array}{l}\text { Contamination of young } \\
\text { carbon }\end{array}$ \\
\hline
\end{tabular}

\subsection{Integration with related data}

In some cases, measurements beyond stable oxygen, hydrogen, and carbon isotopes are published with the isotope data that are useful for data interpretation. For example, strontium isotope data may be useful for constraining 
drainage sources in lacustrine carbonates. Similarly, if multiple measurements are made from different locations on a sample (such as mammal teeth) it can be useful to know the distance along the sample where the material was taken. In order to include these complementary data we add six generic data entry columns - three to define data types ("Other_data_type_X") and three to define data values ("Other_data_value_X"). In these columns, the value "X" can be either "1", "2", or "3", and this number links the data type and value. While many publications include data beyond terrestrial stable isotope data, we generally only include other data in these columns if they are directly relevant for contextualizing the isotope data. However, new data entries do not need to follow this guideline and are welcome to include any additional data in these generic columns.

\subsection{Data entry decisions and data upload notebooks}

While we strive to maintain as much of the original information from a given data entry as possible, the data contributor or curator must make some decisions about how the data are entered. These include decisions about what information is included versus omitted in the entry, as well as how to enter information that is unclear or not explicitly defined by the authors. For example, some papers on the Paleocene Eocene Thermal Maximum report data by time relative to the carbon isotope excursion or by stratigraphic height. This practice is useful for the original study, but does not provide a clear path forward for correlating these data with data from other sections that are constrained in time. Though these ages can be left blank, the data may not be queried when a user extracts data by time, thus limiting the search result. A similar issue sometimes emerges for sample coordinates. In some papers, sample locations are shown on a map, but coordinates are not reported in the data tables. The latitude and longitude can be left blank, but at the risk of the data being omitted from geographic queries.

In order to make our data entry practices transparent, we document decisions such as these in Word documents or text files referred to as data upload "notebooks". Each data upload (publication or unpublished dataset entry) has its own notebook and each notebook contains "General notes" and "Next steps". The general notes section includes decisions about data entry such as those discussed above. These decisions are usually also documented in a notes column in the database itself. The next steps section includes updates that can be made to the data entry in the future. These updates might be to ask the corresponding author for clarification in the case of a data entry question, or for additional data if only average values of multiple replicates are reported. In some cases the next steps include entering "other data" that is available in the manuscript but does not fall into any of the stable isotope data columns. The next steps efforts do not involve changes to the data entry that are critical for the isotope data (in this case, the isotope data are not made available in the database). Data upload notebooks are maintained offline as part of the data entry workflow and are currently available upon request. Future versions of the PATCH Lab will permit automatic downloading of these notebooks with the selected data.

\section{THE PATCH LAB PORTAL}

The PATCH Lab portal (https://geocentroid.shinyapps.io/PATCH-Lab/) is the web platform that hosts the database and graphical user interface (GUI) models for simulating oxygen and carbon isotopes. While the models can be used in any capacity, we anticipate they will be most useful for placing quantitative constraints on possible interpretations, testing hypotheses, and constraining the sensitivity of stable isotope ratios to various forcings. Output from data queries and model simulations can be downloaded in .csv format for offline analysis and plotting. Additional code for database queries can also be downloaded from Github (https://github.com/tykukla/PATCH-Lab) for offline use.

\subsection{Querying the isotope database}

Database queries can be completed from the homepage of The PATCH Lab portal (Fig. 4). Here, users will find a variety of filtering options. In the left column, all sample types represented in the database are listed and can be selected for a given download. In the right column, samples can be further queried by time, data interpretation ("Filter for meteoric interpretation"), and long-term conditions ("Filter out transient events"). The meteoric interpretation filter removes any sample values that the original authors did not interpret as reflecting primary meteoric water or fluids (e.g. samples affected by evaporation, diagenesis, etc.). The transient events filter removes local, transient isotope excursions like the Paleocene Eocene Thermal Maximum. This feature is useful for studies looking at long-term mean conditions, such as for stable isotope paleoaltimetry or for broadly-defined modeling experiments (e.g. "Eocene" boundary conditions). Finally, users can select whether to average the output values based on "Measurement number" (averages replicate measurements of a given sample) or "Measurement number \& site" (averages replicates and then 

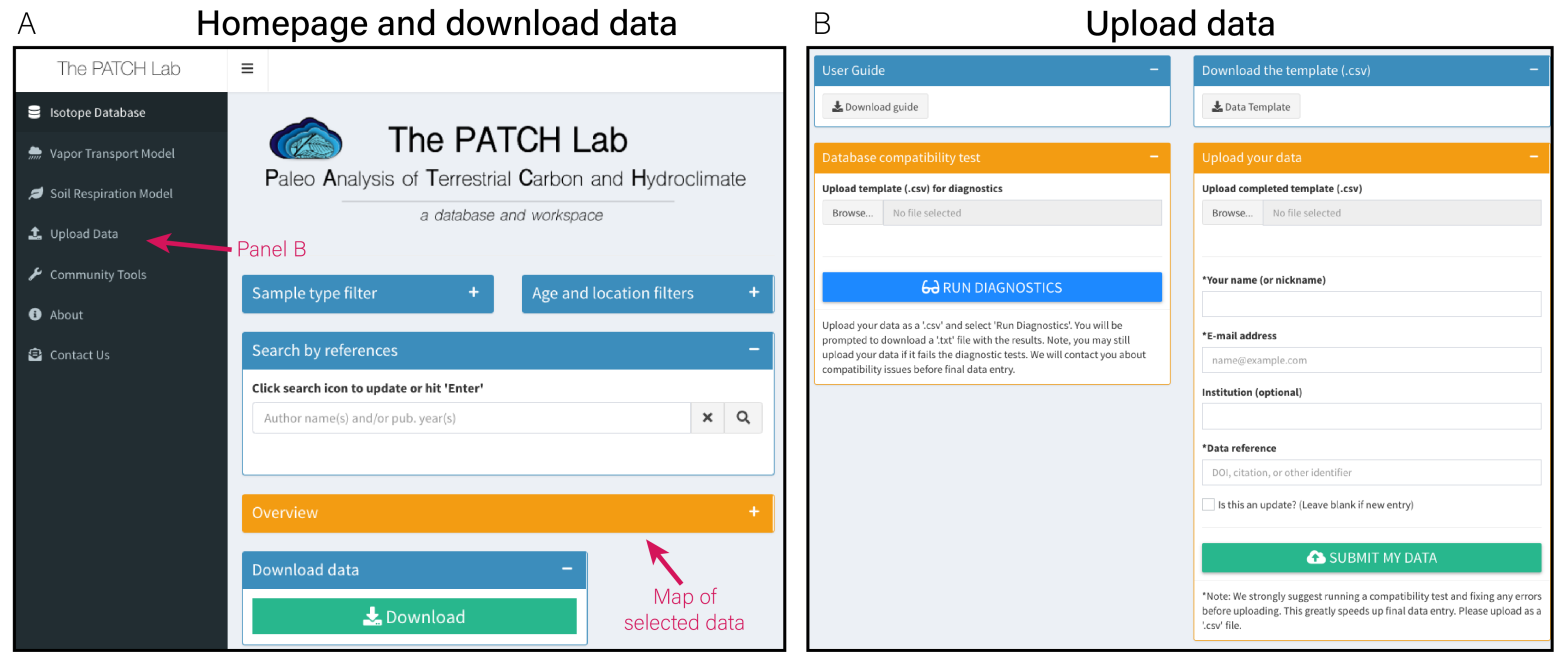

Figure 4. Portal screenshots for the homepage and data upload page. (A) Homepage panels with a plus $(+)$ icon are collapsed. Bar on left shows all pages on the portal. Overview panel shows a map and histogram as in Fig. 1. Green download button returns a .csv file of filtered data. (B) The data upload page has options to download the database user guide and template (blue headers) as well as to test your data spreadsheet for compatibility ("run diagnostics") and submit the data (green button).

all samples of a given site). The entire database can be downloaded by selecting all sample types, the full age range, and no filtering or averaging.

\subsection{Soil respiration model overview}

For nearly four decades, carbon isotopes in paleosols have been modeled using a 1-D production-diffusion equation (Cerling 1984). During that time, a substantial amount of work has refined the soil carbonate paleo-barometer and explored the importance of and controls on the various parameters in the model. For full derivations of the model, we refer the reader to Cerling (1984); Cerling and others, (1993); Davidson (1995); Cerling (1999) and Breecker (2013). Though the paleosol carbonate paleo-barometer has been most frequently used to estimate past atmospheric $\mathrm{pCO}_{2}-$ particularly for periods when there are few other proxies of $\mathrm{pCO}_{2}$, such as in the Paleozoic and Mesozoic-recent workers have also inverted the paleo-barometer to quantitatively examine soil respiration rates (Caves and others, 2014, 2016; Rugenstein \& Chamberlain 2018; Licht and others, 2020). Within The PATCH Lab, we include the ability to model both soil respiration rates and atmospheric $\mathrm{pCO}_{2}$, as well as to forward model and thereby estimate paleosol carbonate $\delta^{13} C$. Using the equations presented in Cerling (1999) and Caves and others, (2016), the built-in soil respiration model includes four different outputs. Output 1 calculates soil respiration at a defined soil column depth given a range of paleosol carbonate $\delta^{13} C$ values as well as other necessary model inputs, such as atmospheric $p C O_{2}$ and its isotopic composition, the isotopic composition of respired soil carbon, and the carbonate formation temperature. The output data are $\delta^{13} C$ and soil respiration rate values for a given depth in the soil column. Output 2 solves for the $\delta^{13} C$ as a function of depth in the soil profile using similar inputs as output 1 as well as the soil respiration rate. Output 3 returns atmospheric $\mathrm{pCO}_{2}$ based on the isotopic composition of soil carbonate and other necessary inputs such as the soil $\mathrm{pCO}_{2}$ and its isotopic composition. Lastly, output 4 reads in carbon isotope data that is defined in age and uses the compilation of paleo-atmospheric $\mathrm{pCO}_{2}$ from the Paleo- $\mathrm{CO}_{2}$ project (https://paleo-co2.org/) to solve for soil respiration rates, propagating the measurement and paleo- $p C \mathrm{O}_{2}$ uncertainties through. We also remove paleosol-based estimates of past atmospheric $\mathrm{pCO}_{2}$ to avoid circularity and impose an upper $p C \mathrm{O}_{2}$ estimate limit of $3000 \mathrm{ppm}$ so the highest values have less effect on both the mean atmospheric $p C \mathrm{O}_{2}$ used and the estimated mean soil respiration.

\subsection{Vapor transport model overview}

The vapor transport model simulates oxygen isotopes in vapor, precipitation, and evapotranspiration over space along a 1-dimensional storm track (Fig. 5). The water balance and isotope ratios are solved simultaneously as a function of the balance of moisture transport (both advective and eddy diffusive), precipitation, and evapotranspiration fluxes. The model is based on the equations of Hendricks and others, (2000), with modifications for continental applications 

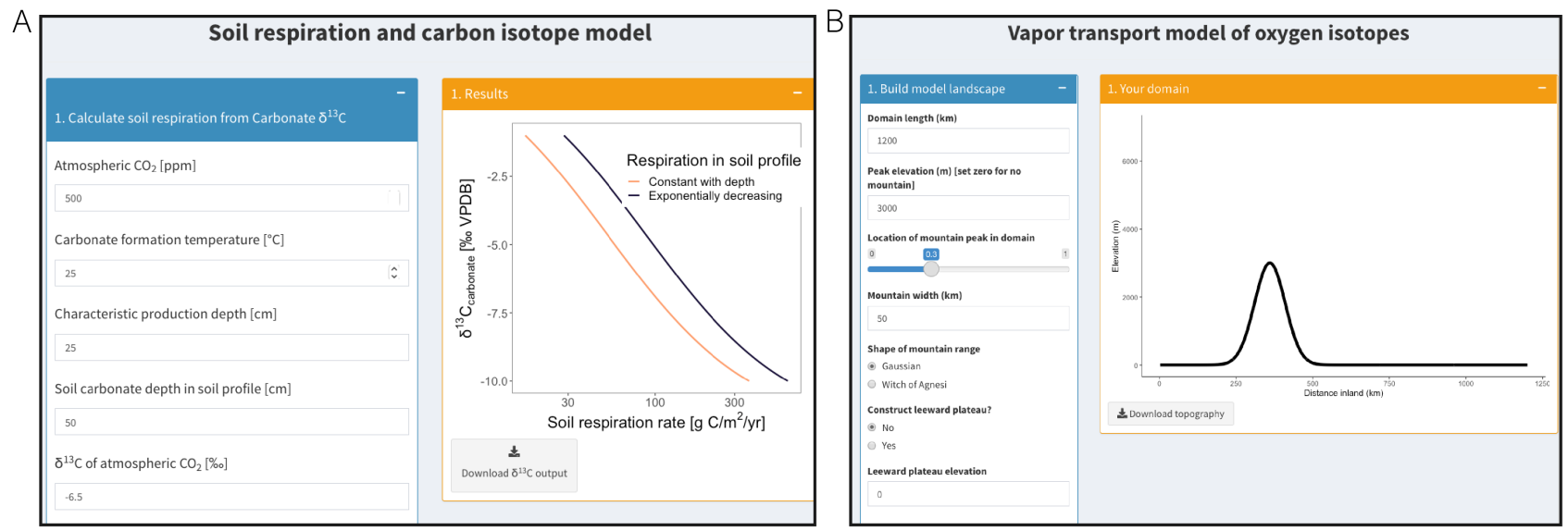

Figure 5. Graphical User Interface (GUI) example screenshots for the (A) $\delta^{13} C$ and (B) $\delta^{18} O$ models. Left columns (blue headers) are used to initialize the model and the right columns (orange headers) display the output. All model output can be downloaded as a .csv file.

from Mix and others, (2013); Chamberlain and others, (2014); Winnick and others, (2014); Caves and others, (2015) and Xia \& Winnick (2021), and the parameterization of orographic rainout and energetic constraints on evapotranspiration of Kukla and others, (2019).

The model is useful for testing hypotheses for climatic and topographic drivers of $\delta^{18} O$ (Carolin and others, 2019; Kukla and others, 2019; Wolf and others, 2020). Previous applications of the model have also used spatial isotope gradients to reconstruct precipitation rates (Kukla and others, 2021a). The GUI version of the model is necessarily limited, but designed to include all of the functionality for flexible single simulations. For the source code of the model, see the supplement of Kukla and others, (2019) or the Github repository (https://github.com/tykukla/Vapor Transport_Model_KuklaEtAl2019).

\section{COMMUNITY ENGAGEMENT}

Community engagement is critical to The PATCH Lab's goal of bringing robust data and modeling tools to a single, easy-to-access location. There are four main avenues for members of the research community to engage with this effort: (1) Data contribution; (2) Update requests; (3) Code contribution; and (4) Long-term project steering.

\subsection{Data contribution}

In addition to data and model downloads, The PATCH Lab portal includes the tools necessary to contribute new data (see Fig. 4). A basic workflow for the data contribution process is shown in Figure 6. Data contributors can begin by downloading the PATCH Lab template that includes all of the data entry columns listed in Table 2 in the correct order. Contributors will also fill out a brief contact sheet so that we can reach out if we have any questions about the data submission.

Once the template is completed, the data contributor can test for compatibility with existing data using the "run diagnostics" button. The contributor is prompted to upload the completed spreadsheet using any filename with a ".csv" extension. At this point, each column is tested against the restrictions imposed on flexible and fixed input columns, and the result of the test is printed to the screen. Isotope ratios are also compared against the entire database to flag outliers that may reflect a data entry error such as a missing decimal point, negative sign, or incorrect isotope standard. The data contributor can upload the data regardless of the test result; however, we encourage contributors to address errors identified by the test and double-check outlier values or include a note about these errors with the data submission.

The PATCH Lab curators will continue to add data to the database and we strive to upload recent publications swiftly. We encourage community contributors to upload their own data to minimize the influence of curators on data entry decisions. 


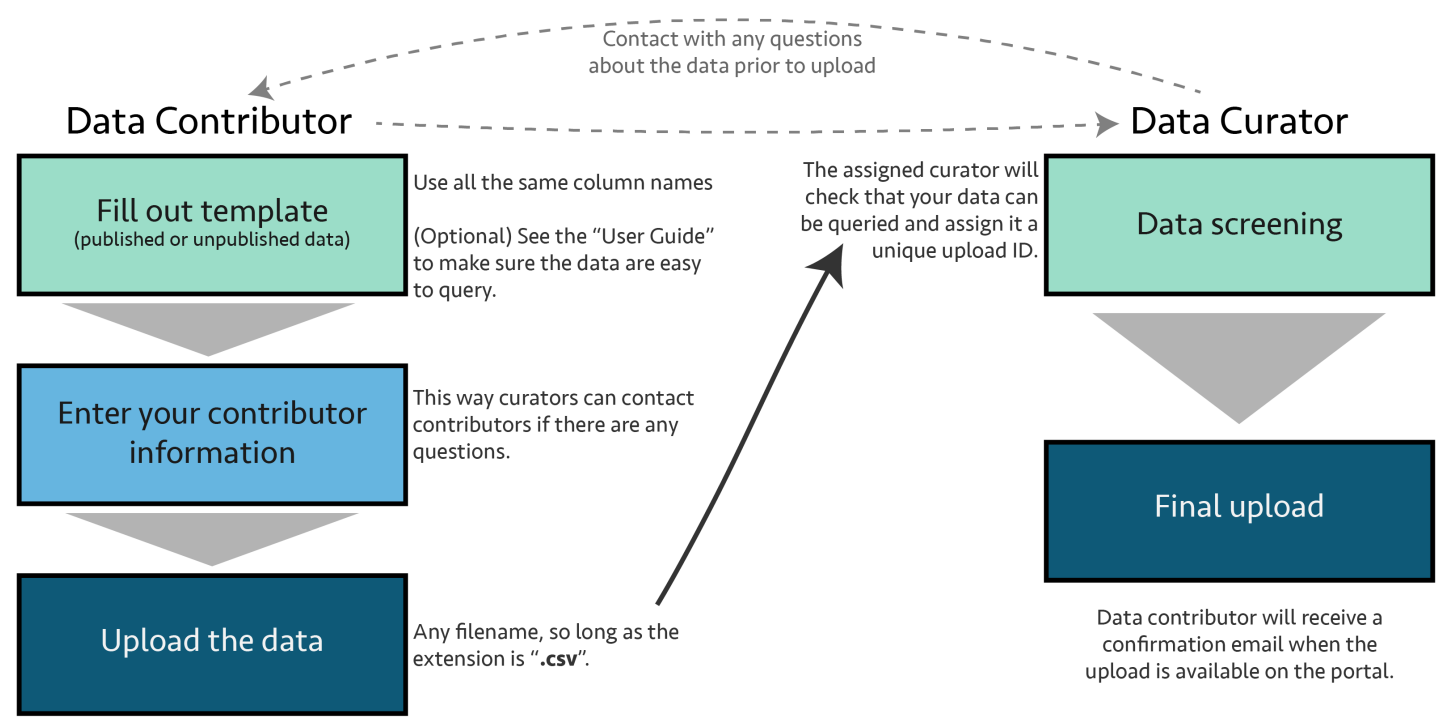

Figure 6. Flow chart of the data upload process.

\subsection{Update requests}

Update requests are useful for a range of applications from fixing data entry errors to updating the broader format of the portal. For example, we recognize that the author of a dataset may not agree with decisions made by the data curators during the data entry process. In this case, we encourage the author to contact the curators directly or submit an update request. These requests can range from a message with update instructions to a completed data template to replace the existing entry. Update requests can also be used by data users that notice errors in existing entries. In this case, we will verify the correct data input from the original publication and make the appropriate changes.

We also welcome feedback and requests that are not related to the database. Users that would like to see new functionality, such as changes to model interfaces or the data query process, can contact the curators via The PATCH Lab portal.

\subsection{Code contribution}

The "Community Tools" page of The PATCH Lab portal hosts links to code developed by the research community that is of interest to other PATCH Lab users. These entries are not restricted to any specific functionality, but some helpful resources include code for processing or plotting data, for running other models, or for integrating other datasets like modern climate, topography, or water isotopes. We also encourage users to contact us about integrating new graphical user interface models into The PATCH Lab portal directly. The portal runs on code written in R, so resources written in $\mathrm{R}$ can be easily adapted to be featured on the portal.

Currently, this page includes links to $\mathrm{R}$ code to work with the database. There are a variety of scripts, including the same data query scripts used by The PATCH Lab portal, for users to build upon or modify. There are also some functions for statistical analysis that is useful for determining statistical power and possible data biases. Scripts like these can be sent to PATCH Lab curators to upload to the Community Tools alongside data from a given publication to improve transparency and reproducibility.

\subsection{Long-term steering committee}

The PATCH Lab is advised by a steering committee to help ensure its long-term success and to stay up to date with the needs of different research communities. The steering committee identifies areas of the resource that can be improved and advises on its long-term infrastructure. The committee includes two distinct groups - an advisory panel and regional editors. The primary role of advisory panel members is to identify long-term goals for the PATCH lab and provide feedback from relevant subdisciplines that frequently use terrestrial stable isotope data. In turn, regional editors handle data curation for certain continents or regions and act to identify new data trends that may impact data curation and archiving. Regional editors also identify and upload data that is missing from the database within 
their region and serve as the point of contact for authors uploading data in their region. Members of the committee are listed in The PATCH Lab portal, and those interested in getting involved are encouraged to reach out via the portal's contact page.

\section{CONCLUDING REMARKS}

The PATCH Lab is an online workspace that integrates terrestrial stable isotope data and models for efficient data download and analysis. Previous and ongoing research already leverages the rapid increase in data of the past two decades. However, synthesizing these data on a case-by-case basis will become more challenging and time intensive as the total amount of available data grows. The goal of this effort is to provide a long-term, curated database for research purposes, alongside tools that can assist in data interpretation.

We emphasize that community engagement in this effort is critical to its utility. The PATCH Lab is a tool developed for the terrestrial paleoclimate and environment community - a community that spans a wide range of disciplines and sub-disciplines, each of which may find the tool useful for different reasons. Feedback from, and engagement with, the research community are the most effective ways to ensure this resource remains useful as science progresses.

\section{ACKNOWLEDGMENTS}

We thank all of the researchers who generated the stable isotope data compiled in The PATCH Lab. We are also grateful to Hari Mix, Danielle Y. Moragne, and Sam Kramer for their contributions compiling data. We thank Katharina Methner for valuable conversations about the database structure, and Caitlin Mothes and Matthew Ross of the CSU Geospatial Centroid for assistance in hosting the PATCH Lab application. This work was funded by NSF EAR-1322084.

\section{REFERENCES}

Abels, H. A., Clyde, W. C., Gingerich, P. D., and others,. 2012, Nature Geoscience, 5, 326, doi: 10.1038/ngeo1427

Abruzzese, M. J., Waldbauer, J. R., \& Chamberlain, C. P. 2005, Geochimica et Cosmochimica Acta, 69, 1377, doi: 10.1016/j.gca.2004.08.036

Alçiçek, H., \& Jiménez-Moreno, G. 2013, Sedimentary Geology, 291, 62, doi: 10.1016/j.sedgeo.2013.03.014

Alonso-Zarza, A., \& Arenas, C. 2004, Sedimentary Geology, 167, 91, doi: 10.1016/j.sedgeo.2004.02.001

Amundson, R., Chadwick, O., Kendall, C., \& Wang, Y. 1996, Geology, 24, 23, doi: 10.1130/0091-7613

Anadón, P., Oms, O., Riera, V., \& Julià, R. 2015, Quaternary International, 389, 70, doi: $10.1016 /$ j.quaint.2014.09.062

Andrews, J. E., Riding, R., \& Dennis, P. F. 1997, Palaeogeography, Palaeoclimatology, Palaeoecology, 129, 171, doi: 10.1016/S0031-0182(96)00120-4

Arehart, G. B., \& O'Neil, J. R. 1993, in Geophysical Monograph Series, ed. P. K. Swart, K. C. Lohmann, J. Mckenzie, \& S. Savin (Washington, D. C.: American Geophysical Union), 277-284, doi: 10.1029/GM078p0277 Arenas, C., Casanova, J., \& Pardo, G. 1997, Palaeogeography, Palaeoclimatology, Palaeoecology, 128, 133, doi: 10.1016/S0031-0182(96)00052-1
384

385

386
Arppe, L., \& Karhu, J. 2010, Quaternary Science Reviews, 29, 1263, doi: 10.1016/j.quascirev.2010.02.013

Atsawawaranunt, K., Comas-Bru, L., Mozhdehi, S. A., and others,. 2018, Earth System Science Data, 10, 1687

Baczynski, A. A., McInerney, F. A., Wing, S. L., and others,. 2013, Geochemistry, Geophysics, Geosystems, 14, 4133, doi: 10.1002/ggge.20265

Bailey, A., Posmentier, E., \& Feng, X. 2018, Geophysical Research Letters, 45, 7093, doi: 10.1029/2018GL078254

Bajnóczi, B., Horváth, Z., Demény, A., \& Mindszenty, A. 2006, Isotopes in Environmental and Health Studies, 42, 335, doi: 10.1080/10256010600991045

Ballato, P., Mulch, A., Landgraf, A., and others,. 2010, Earth and Planetary Science Letters, 300, 125, doi: 10.1016/j.epsl.2010.09.043

Bataille, C. P., Watford, D., Ruegg, S., Lowe, A., \& Bowen, G. J. 2016, Palaeogeography, Palaeoclimatology, Palaeoecology, 457, 277, doi: 10.1016/j.palaeo.2016.06.023

Belem, A., Bell, T., Burdett, H. L., and others,. 2022, Earth and Space Science, 9, doi: 10.1029/2021EA002115

Bentaleb, I., Langlois, C., Martin, C., and others,. 2006, Comptes Rendus Geoscience, 338, 172, doi: $10.1016 /$ j.crte.2005.11.007 
Bershaw, J., Cassel, E. J., Carlson, T. B., Streig, A. R., \& Streck, M. J. 2019, Journal of Volcanology and Geothermal Research, 381, 157, doi: 10.1016/j.jvolgeores.2019.05.021

Bershaw, J., Garzione, C. N., Schoenbohm, L., Gehrels, G., \& Tao, L. 2012, Journal of Asian Earth Sciences, 44, 136, doi: 10.1016/j.jseaes.2011.04.020

Bill, N. S., Mix, H. T., Clark, P. U., and others,. 2018, Earth and Planetary Science Letters, 482, 300, doi: 10.1016/j.epsl.2017.11.029

Boardman, G. S., \& Secord, R. 2013, Palaeogeography, Palaeoclimatology, Palaeoecology, 375, 38, doi: $10.1016 /$ j.palaeo.2013.02.010

Botsyun, S., \& Ehlers, T. A. 2021, Frontiers in Earth Science, 9, 624542, doi: 10.3389/feart.2021.624542

Bougeois, L., Dupont-Nivet, G., de Rafélis, M., and others,. 2018, Earth and Planetary Science Letters, 485, 99, doi: 10.1016/j.epsl.2017.12.036

Bowen, G. J., \& Beitler Bowen, B. 2008, Geology, 36, 379, doi: 10.1130/G24597A.1

Bowen, G. J., Koch, P. L., Gingerich, P. D., and others,. 2001, in Paleocene-Eocene Stratigraphy and Biotic Change in the Bighorn and Clarks Fork Basins, Wyoming No. 33 (University of Michigan Papers on Paleontology), 73-88

Bowen, G. J., Koch, P. L., Meng, J., Ye, J., \& Ting, S. 2005, American Museum Novitates, 3474, 1, doi: 10.1206/0003-0082(2005)474[0001: AACOFL]2.0.CO;2

Bowen, G. J., Maibauer, B. J., Kraus, M. J., and others,. 2014, Nature Geoscience, 8, 44, doi: 10.1038/ngeo2316 Breecker, D., \& Retallack, G. 2014, Palaeogeography, Palaeoclimatology, Palaeoecology, 406, 1, doi: $10.1016 /$ j.palaeo.2014.04.012

Breecker, D. O. 2013, Geochemistry, Geophysics, Geosystems, 14, 3210, doi: 10.1002/ggge.20189

Burgener, L., Hyland, E., Huntington, K. W., Kelson, J. R., \& Sewall, J. O. 2019, Palaeogeography,

Palaeoclimatology, Palaeoecology, 516, 244, doi: 10.1016/j.palaeo.2018.12.004

Campani, M., Mulch, A., Kempf, O., Schlunegger, F., \& Mancktelow, N. 2012, Earth and Planetary Science Letters, 337-338, 174, doi: 10.1016/j.epsl.2012.05.017

Carolin, S. A., Ersek, V., Roberts, W. H. G., Walker, R. T., \& Henderson, G. M. 2019, Geophysical Research Letters, 46, 14003, doi: 10.1029/2019GL084365

Carroll, A. R., Doebbert, A. C., Booth, A. L., and others,. 2008, Geology, 36, 791, doi: 10.1130/G24783A.1

455 Cassel, E. J., Breecker, D. O., Henry, C. D., Larson, T. E.,

\section{\& Stockli, D. F. 2014, Geology, 42, 1007,} doi: 10.1130/G35924.1

Cassel, E. J., Graham, S. A., \& Chamberlain, C. P. 2009, Geology, 37, 547, doi: 10.1130/G25572A.1

Cassel, E. J., Graham, S. A., Chamberlain, C. P., \& Henry, C. D. 2012, Geosphere, 8, 229, doi: 10.1130/GES00671.1

Cassel, E. J., Smith, M. E., \& Jicha, B. R. 2018, Geophysical Research Letters, 45, doi: 10.1029/2018GL079887

Caves, J. K. 2017, GSA Today, doi: 10.1130/GSATG305A.1

Caves, J. K., Sjostrom, D. J., Mix, H. T., Winnick, M. J., \& Chamberlain, C. P. 2014, American Journal of Science, 314, 1171, doi: 10.2475/08.2014.01

Caves, J. K., Winnick, M. J., Graham, S. A., and others,. 2015, Earth and Planetary Science Letters, 428, 33, doi: 10.1016/j.epsl.2015.07.023

Caves, J. K., Moragne, D. Y., Ibarra, D. E., and others,. 2016, Geology, 44, in press, doi: 10.1130/G38267.1

Cerling, T. E. 1984, Earth and Planetary Science Letters, 71, 229, doi: 10.1016/0012-821X(84)90089-X

-. 1999, in Palaeoweathering, Palaeosurfaces and Related Continental Deposits, ed. M. Thiry \& R. Simon-Coinçon (Oxford, UK: Blackwell Publishing Ltd.), 43-60, doi: 10.1002/9781444304190.ch2

Cerling, T. E., Wang, Y., \& Quade, J. 1993, Nature, 361, 344, doi: 10.1038/361344a0

Chamberlain, C., Ibarra, D., Lloyd, M., and others,. 2020, Geochemical Perspectives Letters, 15, 6, doi: 10.7185/geochemlet.2026

Chamberlain, C. P., Mix, H. T., Mulch, A., and others,. 2012, American Journal of Science, 312, 213, doi: 10.2475/02.2012.05

Chamberlain, C. P., Winnick, M. J., Mix, H. T., Chamberlain, S. D., \& Maher, K. 2014, Global Biogeochemical Cycles, 28, 992, doi: 10.1002/2014GB004822

Charreau, J., Kent-Corson, M. L., Barrier, L., and others,. 2012, Earth and Planetary Science Letters, 341-344, 158, doi: 10.1016/j.epsl.2012.05.033

Clyde, W. C., Ting, S., Snell, K. E., and others,. 2010, The Journal of Geology, 118, 131, doi: 10.1086/649893

Comas-Bru, L., Rehfeld, K., Roesch, C., and others,. 2020, Earth System Science Data, 12, 2579, doi: 10.5194/essd-12-2579-2020

Criss, R. E., \& Taylor, H. P. 1983, GSA Bulletin, 94, 640

Crowley, B. E., Koch, P. L., \& Davis, E. B. 2008, Geological Society of America Bulletin, 120, 588, doi: 10.1130/B26254.1 
Csonka, D., Bradák, B., Barta, G., and others,. 2020, Quaternary International, 552, 25, doi: 10.1016/j.quaint.2019.07.021

Currie, B. S., Polissar, P. J., Rowley, D. B., and others,. 2016, American Journal of Science, 316, 401, doi: 10.2475/05.2016.01

Currie, B. S., Rowley, D. B., \& Tabor, N. J. 2005, Geology, 33, 181, doi: 10.1130/G21170.1

Cyr, A. J., Currie, B. S., \& Rowley, D. B. 2005, The Journal of Geology, 113, 517, doi: 10.1086/431907

Da, J., Zhang, Y. G., Li, G., Meng, X., \& Ji, J. 2019, Nature Communications, 10, 4342, doi: 10.1038/s41467-019-12357-5

Davidson, G. R. 1995, Geochimica et Cosmochimica Acta, 59, 2485, doi: 10.1016/0016-7037(95)00143-3

Davis, S. J., Mix, H. T., Wiegand, B. A., Carroll, A. R., \& Chamberlain, C. P. 2009a, American Journal of Science, 309, 549, doi: 10.2475/07.2009.02

Davis, S. J., Mulch, A., Carroll, A. R., Horton, T. W., \& Chamberlain, C. P. 2009b, Geological Society of America Bulletin, preprint, 1, doi: 10.1130/B26308.1

Davis, S. J., Wiegand, B. A., Carroll, A. R., \& Chamberlain, C. P. 2008, Earth and Planetary Science Letters, 275, 258, doi: 10.1016/j.epsl.2008.08.009

Dean, J. R., Jones, M. D., Leng, M. J., and others,. 2015, Quaternary Science Reviews, 124, 162, doi: 10.1016/j.quascirev.2015.07.023

DeCelles, P. G., Kapp, P., Quade, J., \& Gehrels, G. E. 2011, Geological Society of America Bulletin, 123, 1337, doi: 10.1130/B30258.1

DeCelles, P. G., Quade, J., Kapp, P., and others,. 2007, Earth and Planetary Science Letters, 253, 389, doi: 10.1016/j.epsl.2006.11.001

Dee, S., Emile-Geay, J., Evans, M. N., and others,. 2015a, Journal of Advances in Modeling Earth Systems, 7, 1220, doi: 10.1002/2015MS000447

Dee, S., Noone, D., Buenning, N., Emile-Geay, J., \& Zhou, Y. 2015b, Journal of Geophysical Research: Atmospheres, 120, 73, doi: 10.1002/2014JD022194

Dee, S. G., Russell, J. M., Morrill, C., Chen, Z., \& Neary, A. 2018, Paleoceanography and Paleoclimatology, 33, 1250, doi: 10.1029/2018PA003413

Dettman, D. L., Fang, X., Garzione, C. N., \& Li, J. 2003, Earth and Planetary Science Letters, 214, 267, doi: 10.1016/S0012-821X(03)00383-2

Dettman, D. L., Kohn, M. J., Quade, J., and others,. 2001, Geology, 29, 31, doi: 10.1130/0091-7613(2001)029〈0031:SSIEFA〉2.0.CO;2

Dettman, D. L., \& Lohmann, K. C. 2000, Geology, 28, 243, doi: 10.1130/0091-7613(2000)28<243
555

556

557
554 Ding, L., Xu, Q., Yue, Y., and others,. 2014, Earth and Planetary Science Letters, 392, 250, doi: 10.1016/j.epsl.2014.01.045

Ding, Z. L., \& Yang, S. L. 2000, Palaeogeography, Palaeoclimatology, Palaeoecology, 291

Doebbert, A. C., Carroll, A. R., Mulch, A., Chetel, L. M., \& Chamberlain, C. P. 2010, Geological Society of America Bulletin, 122, 236, doi: 10.1130/B26522.1

Domingo, L., Koch, P. L., Hernández Fernández, M., and others,. 2013, PLoS ONE, 8, e63739, doi: 10.1371/journal.pone.0063739

Dong, J., Liu, Z., An, Z., and others,. 2018, Journal of Asian Earth Sciences, 158, 153, doi: 10.1016/j.jseaes.2018.02.014

Ekart, D. D., Cerling, T. E., Montañez, I. P., \& Tabor, N. J. 1999, American Journal of Science, 299, 805

Eren, M. 2011, Geochemistry, 71, 31, doi: 10.1016/j.chemer.2010.12.002

Evans, M., Tolwinski-Ward, S., Thompson, D., \& Anchukaitis, K. 2013, Quaternary Science Reviews, 76, 16, doi: 10.1016/j.quascirev.2013.05.024

Fan, M., Ayyash, S. A., Tripati, A., Passey, B. H., \& Griffith, E. M. 2018, GSA Bulletin, 130, 1073, doi: 10.1130/B31732.1

Fan, M., Constenius, K. N., \& Dettman, D. L. 2017, Earth and Planetary Science Letters, 457, 376, doi: 10.1016/j.epsl.2016.10.038

Fan, M., Constenius, K. N., Phillips, R. F., \& Dettman, D. L. 2021, GSA Bulletin, doi: 10.1130/B35919.1

Fan, M., Decelles, P. G., Gehrels, G. E., and others,. 2011, GSA Bulletin, 979, doi: 10.1130/B30235.1

Fan, M., \& Dettman, D. L. 2009, Earth and Planetary Science Letters, 286, 110, doi: 10.1016/j.epsl.2009.06.024

Fan, M., Heller, P., Allen, S. D., \& Hough, B. G. 2014a, Geology, 42, 547, doi: 10.1130/G35444.1

Fan, M., Hough, B. G., \& Passey, B. H. 2014b, Earth and Planetary Science Letters, 408, 35, doi: 10.1016/j.epsl.2014.09.050

Foreman, B. Z., Fricke, H. C., Lohmann, K. C., \& Rogers, R. R. 2011, PALAIOS, 26, 545, doi: 10.2110/palo.2010.p10-133r

Foreman, B. Z., Roberts, E. M., Tapanila, L., Ratigan, D., \& Sullivan, P. 2015, Cretaceous Research, 56, 180, doi: 10.1016/j.cretres.2015.05.001

Fox, D. L., Honey, J. G., Martin, R. A., \& Pelaez-Campomanes, P. 2012, Geological Society of America Bulletin, 124, 444, doi: 10.1130/B30401.1

Fox, D. L., \& Koch, P. L. 2003, Geology, 31, 809, doi: 10.1130/G19580.1 
—. 2004, Palaeogeography, Palaeoclimatology,

Palaeoecology, 207, 305, doi: 10.1016/S0031-0182(04)00045-8

Fox, D. L., Pau, S., Taylor, L., and others,. 2018, Frontiers in Ecology and Evolution, 6, 147, doi: $10.3389 /$ fevo.2018.00147

Fricke, H. C. 2003, Geological Society of America Bulletin, 115, 1088, doi: 10.1130/B25249.1

Fricke, H. C., Clyde, W. C., O'Neil, J. R., \& Gingerich, P. D. 1998, Earth and Planetary Science Letters, 160, 193, doi: 10.1016/S0012-821X(98)00088-0

Fricke, H. C., Foreman, B. Z., \& Sewall, J. O. 2010, Earth and Planetary Science Letters, 289, 11, doi: 10.1016/j.epsl.2009.10.018

Fricke, H. C., Rogers, R. R., Backlund, R., Dwyer, C. N., \& Echt, S. 2008, Palaeogeography, Palaeoclimatology, Palaeoecology, 266, 13, doi: 10.1016/j.palaeo.2008.03.030

Fricke, H. C., \& Wing, S. L. 2004, American Journal of Science, 304, 612

Gallant, C. E., Candy, I., van den Bogaard, P., Silva, B. N., \& Turner, E. 2014, Boreas, 43, 818, doi: 10.1111/bor.12065

Gao, Y., Ibarra, D. E., Caves Rugenstein, J. K., and others,. 2021, Earth-Science Reviews, 216, 103572, doi: 10.1016/j.earscirev.2021.103572

Garzione, C. N., Dettman, D. L., Quade, J., DeCelles, P. G., \& Butler, R. F. 2000, 4

Gébelin, A., Mulch, A., Teyssier, C., Page Chamberlain, C. \& Heizler, M. 2012, Earth and Planetary Science Letters, 335-336, 36, doi: 10.1016/j.epsl.2012.04.029

Genty, D., Blamart, D., Ouahdi, R., and others,. 2003,

Nature, 421, 833, doi: 10.1038/nature01391

Ghosh, P., Padia, J., \& Mohindra, R. 2004, Palaeogeography, Palaeoclimatology, Palaeoecology, 206, 103, doi: 10.1016/j.palaeo.2004.01.014

Godfrey, C., Fan, M., Jesmok, G., Upadhyay, D., \& Tripati, A. 2018, Sedimentary Geology, 367, 69, doi: $10.1016 /$ j.sedgeo.2018.02.006

Harris, E. B., Kohn, M. J., \& Strömberg, C. A. 2020, Palaeogeography, Palaeoclimatology, Palaeoecology, 546, 109610, doi: 10.1016/j.palaeo.2020.109610

Harzhauser, M., Latal, C., \& Piller, W. E. 2007, Palaeogeography, Palaeoclimatology, Palaeoecology, 249, 335, doi: 10.1016/j.palaeo.2007.02.006

Harzhauser, M., Mandic, O., Latal, C., \& Kern, A. 2012, Hydrobiologia, 682, 27, doi: 10.1007/s10750-011-0618-3

Heitmann, E. O., Ji, S., Nie, J., \& Breecker, D. O. 2017, Earth and Planetary Science Letters, 474, 272, doi: 10.1016/j.epsl.2017.06.006
652 Hellwig, A., Voigt, S., Mulch, A., and others,. 2018, Sedimentology, 65, 517, doi: 10.1111/sed.12390

Hendricks, M. B., DePaolo, D. J., \& Cohen, R. C. 2000, Global Biogeochemical Cycles, 14, 851

Hofman-Kamińska, E., Bocherens, H., Borowik, T., Drucker, D. G., \& Kowalczyk, R. 2018, PLOS ONE, 13, e0190723, doi: 10.1371/journal.pone.0190723

Hoke, G. D., Liu-Zeng, J., Hren, M. T., Wissink, G. K., \& Garzione, C. N. 2014, Earth and Planetary Science Letters, 394, 270, doi: 10.1016/j.epsl.2014.03.007

Honegger, L., Adatte, T., Spangenberg, J. E., and others,. 2020, Climate of the Past, 16, 227, doi: 10.5194/cp-16-227-2020

Horton, T., Sjostrom, D., Abruzzese, M., and others,. 2004, American Journal of Science, 304, 862

Horton, T. W., \& Chamberlain, C. P. 2006, Bulletin of the Geological Society of America, 118, 475, doi: 10.1130/B25808

Hough, B. G., Fan, M., \& Passey, B. H. 2014, Earth and Planetary Science Letters, 391, 110, doi: 10.1016/j.epsl.2014.01.008

Hough, B. G., Garzione, C. N., Wang, Z., and others,. 2011, Geological Society of America Bulletin, 123, 168, doi: 10.1130/B30090.1

Hren, M. T., Pagani, M., Erwin, D. M., \& Brandon, M. 2010, Geology, 38, 7, doi: 10.1130/G30215.1

Huntington, K. W., Budd, D. A., Wernicke, B. P., \& Eiler, J. M. 2011, Journal of Sedimentary Research, 81, 656, doi: $10.2110 /$ jsr.2011.51

Huntington, K. W., Wernicke, B. P., \& Eiler, J. M. 2010, Tectonics, 29, 2009TC002449, doi: 10.1029/2009TC002449

Huntington, K. W., Eiler, J. M., Affek, H. P., and others, 2009, Journal of Mass Spectrometry, 44, 1318, doi: $10.1002 /$ jms.1614

Huyghe, D., Emmanuel, L., Renard, M., and others,. 2017, Palaeogeography, Palaeoclimatology, Palaeoecology, 485, 247, doi: 10.1016/j.palaeo.2017.06.017

Hyland, E., Sheldon, N. D., \& Fan, M. 2013, Geological Society of America Bulletin, 125, 1338, doi: 10.1130/B30761.1

Hyland, E. G., \& Sheldon, N. D. 2013, Palaeogeography, Palaeoclimatology, Palaeoecology, 369, 125, doi: 10.1016/j.palaeo.2012.10.011

Ibarra, D. E., \& Chamberlain, C. P. 2015, American Journal of Science, 315, 781, doi: 10.2475/09.2015.01

Ibarra, D. E., Kukla, T., Methner, K. A., Mulch, A., \& Chamberlain, C. P. 2021, Frontiers in Earth Science, 9, 628868, doi: 10.3389/feart.2021.628868 
Ingalls, M., Rowley, D., Olack, G., and others,. 2018, GSA Bulletin, 130, 307, doi: 10.1130/B31723.1

Jensen, T. Z. T., Sjöström, A., Fischer, A., and others,. 2020, Scientific Reports, 10, 17244, doi: 10.1038/s41598-020-74258-8

Ji, S., Nie, J., Lechler, A., and others,. 2018, Earth and Planetary Science Letters, 499, 134, doi: 10.1016/j.epsl.2018.07.011

Jiang, W. 2002, Chinese Science Bulletin, 47, 687, doi: $10.1360 / 02$ tb9156

Jolivet, M., \& Boulvais, P. 2021, Geoscience Frontiers, 12, 101132, doi: 10.1016/j.gsf.2020.12.012

Kaakinen, A., Sonninen, E., \& Lunkka, J. P. 2006, Palaeogeography, Palaeoclimatology, Palaeoecology, 237, 359, doi: 10.1016/j.palaeo.2005.12.011

Kelson, J. R., Watford, D., Bataille, C., and others,. 2018, Paleoceanography and Paleoclimatology, 33, 1230, doi: 10.1029/2018PA003391

Kent-Corson, M. L., Barnosky, A. D., Mulch, A., Carrasco, M. A., \& Chamberlain, C. P. 2013, Palaeogeography, Palaeoclimatology, Palaeoecology, 387, 17, doi: 10.1016/j.palaeo.2013.07.014

Kent-Corson, M. L., Mulch, A., Graham, S. A., and others,. 2010, Basin Research, 22, 829, doi: 10.1111/j.1365-2117.2009.00456.x

Kent-Corson, M. L., Ritts, B. D., Zhuang, G., and others,. 2009, Earth and Planetary Science Letters, 282, 158, doi: 10.1016/j.epsl.2009.03.011

Kent-Corson, M. L., Sherman, L. S., Mulch, A., \& Chamberlain, C. P. 2006, Earth and Planetary Science Letters, 252, 453, doi: 10.1016/j.epsl.2006.09.049

Kluge, T., \& Affek, H. P. 2012, Quaternary Science Reviews, 49, 82, doi: 10.1016/j.quascirev.2012.06.013

Koch, P. L., Clyde, W. C., Hepple, R. P., and others,. 2003, GSA Special Papers, 49

Koch, P. L., Zachos, J. C., \& Dettman, D. L. 1995, Palaeogeography, Palaeoclimatology, Palaeoecology, 61 Kocsis, L., Ozsvárt, P., Becker, D., and others,. 2014, Geology, 42, 727, doi: 10.1130/G35673.1

Kohn, M. J., \& Law, J. M. 2006, Geochimica et Cosmochimica Acta, 70, 931, doi: $10.1016 /$ j.gca.2005.10.023

Kohn, M. J., Miselis, J. L., \& Fremd, T. J. 2002, Earth and Planetary Science Letters, 204, 151, doi: 10.1016/S0012-821X(02)00961-5

Konecky, B. L., McKay, N. P., Churakova (Sidorova), O. V., and others,. 2020, Earth System Science Data, 12, 2261, doi: 10.5194/essd-12-2261-2020
749

750

751

752

753

754

755

756
Kovács, J., Moravcová, M., Újvári, G., \& Pintér, A. G. 2012, Quaternary International, 276-277, 145, doi: 10.1016/j.quaint.2012.04.009

Kovács, J., Szabó, P., Kocsis, L., and others,. 2015, Palaeogeography, Palaeoclimatology, Palaeoecology, 440, 455, doi: 10.1016/j.palaeo.2015.09.019

Kovda, I., Mora, C. I., \& Wilding, L. P. 2008, Journal of Plant Nutrition and Soil Science, 171, 498, doi: 10.1002/jpln.200700037

Küçükuysal, C., \& Kapur, S. 2014, Geologica Carpathica, 65, 243, doi: 10.2478/geoca-2014-0014

Kukla, T., Ahlström, A., Maezumi, S. Y., and others, 2021a, Global and Planetary Change, 202, 103520, doi: 10.1016/j.gloplacha.2021.103520

Kukla, T., Ibarra, D., Caves Rugenstein, J. K., and others,. 2021b, Frontiers in Earth Science, 9, 9

Kukla, T., Winnick, M. J., Maher, K., Ibarra, D. E., \& Chamberlain, C. P. 2019, Journal of Geophysical Research: Atmospheres, 124, 563, doi: 10.1029/2018JD029571

Lacroix, B., \& Niemi, N. A. 2019, Geochimica et Cosmochimica Acta, 247, 40, doi: 10.1016/j.gca.2018.12.016

Latorre, C., Quade, J., \& McIntosh, W. C. 1997, Earth and Planetary Science Letters, 146, 83, doi: 10.1016/S0012-821X(96)00231-2

Leary, R. J., Quade, J., DeCelles, P. G., \& Reynolds, A. 2017, Geology, 45, 399, doi: 10.1130/G38830.1

Lechler, A. R., \& Niemi, N. A. 2011, Geology, 39, 379, doi: 10.1130/G31535.1

Leone, G., Bonadonna, F., \& Zanchetta, G. 2000, Palaeogeography, Palaeoclimatology, Palaeoecology, 163, 115, doi: 10.1016/S0031-0182(00)00148-6

Li, B., Sun, D., Wang, X., and others,. 2016a, Journal of Asian Earth Sciences, 125, 22, doi: 10.1016/j.jseaes.2016.05.010

Li, L., Fan, M., \& Zhu, L. 2021, Tectonics, 40, doi: 10.1029/2020TC006671

Li, L., Garzione, C. N., Pullen, A., \& Chang, H. 2016b, Palaeogeography, Palaeoclimatology, Palaeoecology, 461, 201, doi: 10.1016/j.palaeo.2016.08.025

Li, S., Currie, B. S., Rowley, D. B., \& Ingalls, M. 2015, Earth and Planetary Science Letters, 432, 415, doi: 10.1016/j.eps1.2015.09.044

Licht, A., van Cappelle, M., Abels, H. A., and others,. 2014, Nature, 513, 501, doi: 10.1038/nature13704

Licht, A., Quade, J., Kowler, A., and others,. 2017a, American Journal of Science, 317, 1, doi: $10.2475 / 01.2017 .01$ 
Licht, A., Coster, P., Ocakoğlu, F., and others,. 2017b, Journal of Asian Earth Sciences, 143, 45, doi: 10.1016/j.jseaes.2017.03.033

Licht, A., Dupont-Nivet, G., Meijer, N., and others,. 2020, Palaeogeography, Palaeoclimatology, Palaeoecology, 560, 110016, doi: 10.1016/j.palaeo.2020.110016

Liu, W., Liu, Z., An, Z., and others,. 2014, Proceedings of the National Academy of Sciences, 111, 16292, doi: 10.1073/pnas.1410890111

Lüdecke, T., Mikes, T., Rojay, F. B., Cosca, M. A., \& Mulch, A. 2013, Turkish Journal of Earth Sciences, 793

Lukens, W. E., Driese, S. G., Peppe, D. J., \& Loudermilk, M. 2017, Palaeogeography, Palaeoclimatology,

Palaeoecology, 485, 361, doi: 10.1016/j.palaeo.2017.06.026 Macaulay, E. A., Sobel, E. R., Mikolaichuk, A., and others,. 2016, Basin Research, 28, 57, doi: 10.1111/bre.12098

Mack, G. H., \& Cole, D. R. 2005, Sedimentary Geology, 174, 115, doi: 10.1016/j.sedgeo.2004.12.002

Mack, G. H., Cole, D. R., James, W. C., Giordano, T. H., \& Salyards, S. L. 1994, American Journal of Science, 294, 621

Matson, S. D., \& Fox, D. L. 2010, Palaeogeography, Palaeoclimatology, Palaeoecology, 287, 28, doi: $10.1016 /$ j.palaeo.2009.12.010

Matson, S. D., Rook, L., Oms, O., \& Fox, D. L. 2012, Journal of Human Evolution, 63, 127, doi: 10.1016/j.jhevol.2012.04.004

McFadden, R., Mulch, A., Teyssier, C., \& Heizler, M. 2015, Lithosphere, 7, 355, doi: 10.1130/L429.1

McLean, A., \& Bershaw, J. 2021, Frontiers in Earth Science, 9, 624961, doi: 10.3389/feart.2021.624961

Meijers, M. J., Peynircioğlu, A. A., Cosca, M. A., and others,. 2018, Palaeogeography, Palaeoclimatology, Palaeoecology, 498, 53, doi: 10.1016/j.palaeo.2018.03.001 Meijers, M. J. M., Strauss, B. E., Özkaptan, M., and others,. 2016, Geochemistry, Geophysics, Geosystems, 17 914, doi: 10.1002/2015GC006209

Methner, K., Campani, M., Fiebig, J., and others,. 2020, Scientific Reports, 10, 7989, doi: 10.1038/s41598-020-64743-5

Methner, K., Fiebig, J., Wacker, U., and others,. 2016a, Tectonics, 35, 546, doi: 10.1002/2015TC003984

Methner, K., Mulch, A., Fiebig, J., and others,. 2021, Paleoceanography and Paleoclimatology, 36, doi: 10.1029/2020PA003991

—. 2016b, Earth and Planetary Science Letters, 450, 132, doi: 10.1016/j.epsl.2016.05.053

Methner, K., Mulch, A., Teyssier, C., and others,. 2015, Tectonics, 34, 680, doi: 10.1002/2014TC003766
Mix, H. T., Caves Rugenstein, J. K., Reilly, S. P., and others,. 2019, Earth and Planetary Science Letters, 518, 76, doi: 10.1016/j.epsl.2019.04.050

Mix, H. T., \& Chamberlain, C. P. 2014, Geochimica et Cosmochimica Acta, 141, 532, doi: 10.1016/j.gca.2014.07.008

Mix, H. T., Ibarra, D. E., Mulch, A., Graham, S. A., \& Page Chamberlain, C. 2016, Bulletin of the Geological Society of America, 128, 531, doi: 10.1130/B31294.1

Mix, H. T., Winnick, M. J., Mulch, A., \& Page Chamberlain, C. 2013, Earth and Planetary Science Letters, 377-378, 73, doi: 10.1016/j.epsl.2013.07.032

Mulch, A., Chamberlain, C. P., Cosca, M. A., and others,. 2015, American Journal of Science, 315, 317, doi: $10.2475 / 04.2015 .02$

Mulch, A., Graham, S. A., \& Chamberlain, C. P. 2006, Science, 313, 87, doi: 10.1126/science.1125986

Mulch, A., Perkins, M. E., \& Chamberlain, C. P. 2008, Proceedings of the National Academy of Sciences, 105 Mulch, A., Teyssier, C., Cosca, M. A., \& Chamberlain, C. P. 2007, Tectonics, 26, 1, doi: 10.1029/2006TC001995 Mullin, M. R. D. 2010, MS, Ball State University, Muncie, IN

Nehme, C., Kluge, T., Verheyden, S., and others,. 2020, Quaternary Science Reviews, 250, 106663, doi: $10.1016 /$ j.quascirev.2020.106663

Ortiz, J. E., Torres, T., Delgado, A., and others,. 2006, Palaeogeography, Palaeoclimatology, Palaeoecology, 240, 536, doi: 10.1016/j.palaeo.2006.03.008

Page, M., Licht, A., Dupont-Nivet, G., and others,. 2019, Geology, 47, 203, doi: 10.1130/G45480.1

Passey, B. H., Ayliffe, L. K., Kaakinen, A., and others, 2009, Earth and Planetary Science Letters, 277, 443, doi: 10.1016/j.epsl.2008.11.008

Peryam, T. C., Dorsey, R. J., \& Bindeman, I. 2011, Palaeogeography, Palaeoclimatology, Palaeoecology, 305, 65, doi: 10.1016/j.palaeo.2011.02.014

Peters, S. E., Husson, J. M., \& Czaplewski, J. J. 2018, 1, doi: 10.1029/2018GC007467

Poage, M. A., \& Chamberlain, C. P. 2002, Tectonics, 21, 1034, doi: 10.1029/2001TC001303

Poulson, S. R., \& John, B. E. 2003, Geological Society of America Bulletin, 115, 434, doi: 10.1130/0016-7606(2003)115<0434:SIATEG $>2.0 . C O ; 2$

Quade, J., Cater, J. M. L., Ojha, T. P., and others,. 1995, Geological Society of America Bulletin, 17

Quade, J., \& Cerling, T. E. 1995, Palaeogeography, Palaeoclimatology, Palaeoecology, 115, 91, doi: 10.1016/0031-0182(94)00108-K 
Quade, J., Cerling, T. E., \& Bowman, J. R. 1989, Nature, 342, 189, doi: 10.1038/340301a0

Quade, J., Solounias, N., \& Cerling, T. E. 1994, Palaeogeography, Palaeoclimatology, Palaeoecology, 108, 41, doi: 10.1016/0031-0182(94)90021-3

Retallack, G. J., Wynn, J. G., \& Fremd, T. J. 2004, Geology, 32, 297, doi: 10.1130/G20247.1

Ring, S. J., Bocherens, H., Wings, O., \& Rabi, M. 2020, Scientific Reports, 10, 3987, doi: 10.1038/s41598-020-60379-7

Rothe, P., Hoefs, J., \& Sonne, V. 1974, Sedimentology, 21, 373, doi: 10.1111/j.1365-3091.1974.tb02066.x

Rowe, P., Wickens, L., Sahy, D., and others,. 2020, Palaeogeography, Palaeoclimatology, Palaeoecology, 538, 109422, doi: 10.1016/j.palaeo.2019.109422

Rowley, D. B., \& Currie, B. S. 2006, Nature, 439, 677, doi: 10.1038/nature04506

Rowley, D. B., \& Garzione, C. N. 2007, Annual Review of Earth and Planetary Sciences, 35, 463, doi: 10.1146/annurev.earth.35.031306.140155

Rugenstein, J. K., \& Chamberlain, C. P. 2018, Earth-Science Reviews, doi: 10.1016/j.earscirev.2018.09.003

San Jose, M., Caves Rugenstein, J. K., Cosentino, D., and others,. 2020, Earth and Planetary Science Letters, 544, 116376, doi: 10.1016/j.epsl.2020.116376

Sanyal, P., Bhattacharya, S., Kumar, R., Ghosh, S., \& Sangode, S. 2005, Palaeogeography, Palaeoclimatology, Palaeoecology, 228, 245, doi: 10.1016/j.palaeo.2005.06.007 Saylor, J. E., Quade, J., Dettman, D. L., and others,. 2009, American Journal of Science, 309, 1, doi: 10.2475/01.2009.01

Scherler, L., Tütken, T., \& Becker, D. 2014, Quaternary Research, 82, 378, doi: 10.1016/j.yqres.2014.05.004 Schlunegger, F., Rieke-Zapp, D., \& Ramseyer, K. 2007, Swiss Journal of Geosciences, 100, 383, doi: 10.1007/s00015-007-1238-9

Schwartz, T. M., Methner, K., Mulch, A., Graham, S. A., \& Chamberlain, C. P. 2019, GSA Bulletin, 131, 1203, doi: 10.1130/B32068.1

Sjostrom, D. J., Hren, M. T., Horton, T. W., Waldbauer, J. R., \& Chamberlain, C. P. 2006, Geological Society of America Special Papers, 398, 309, doi: 10.1130/2006.2398(19).

Smith, G. A., Wang, Y., Cerling, T. E., \& Geissman, J. W. 1993, Geology, 21, 691

Smith, M. E., Cassel, E. J., Jicha, B. R., Singer, B. S., \& Canada, A. S. 2017, Earth and Planetary Science Letters, 479, 156, doi: 10.1016/j.epsl.2017.09.023

945 Spencer, J. E., Harris, R. C., Dettman, D., \& Patchett,

946

947

948

949

950

951

952

953
P. J. 1996, Arizona Geological Survey, 23

Stern, L. A., Chamberlain, C. P., Reynolds, R. C., \& Johnson, G. D. 1997, Geochimica et Cosmochimica Acta, 61, 731, doi: 10.1016/S0016-7037(96)00367-5

Strömberg, C. A. E. 2011, Annual Review of Earth and Planetary Sciences, 39, 517, doi: 10.1146/annurev-earth-040809-152402

Suarez, M. B., Passey, B. H., \& Kaakinen, A. 2011, Geology, 39, 1151, doi: 10.1130/G32350.1

Sun, J., Liu, W., Liu, Z., and others,. 2017, Palaeogeography, Palaeoclimatology, Palaeoecology, 485, 189, doi: 10.1016/j.palaeo.2017.06.012

Super, J. 2010, PhD thesis, Stanford University

Tabor, N. J., \& Montañez, I. P. 2005, Palaeogeography, Palaeoclimatology, Palaeoecology, 223, 127, doi: $10.1016 /$ j.palaeo.2005.04.009

Tabor, N. J., Montanez, I. P., \& Southard, R. J. 2002, Geochimica et Cosmochimica Acta, 66, 3093, doi: 10.1016/S0016-7037(02)00879-7

Takeuchi, A. 2007, PhD thesis, Washington State University

Takeuchi, A., Hren, M. T., Smith, S. V., Chamberlain, C. P., \& Larson, P. B. 2010, Chemical Geology, 277, 323, doi: 10.1016/j.chemgeo.2010.08.015

Takeuchi, A., \& Larson, P. B. 2005, Geology, 33, 313, doi: 10.1130/G21335.1

Tang, M., Liu-Zeng, J., Hoke, G. D., and others,. 2017, Tectonophysics, 712-713, 170, doi: $10.1016 /$ j.tecto.2017.05.018

Ting, S., Vowen, G. J., Koch, P. L., and others,. 2003, Biostratigraphic, Chemostratigraphic, and Magnetostratigraphic Study across the Paleocene-Eocene Boundary in the Hengyang Basin, Hunan, China (Geological Society of America), doi: 10.1130/0-8137-2369-8.521

Torres, M. A., \& Gaines, R. R. 2013, Journal of Sedimentary Research, 83, 591, doi: 10.2110/jsr.2013.48 Tütken, T., Vennemann, T., \& Pfretzschner, H.-U. 2008, Palaeogeography, Palaeoclimatology, Palaeoecology, 266, 254, doi: 10.1016/j.palaeo.2008.03.037

Vasilyan, D., \& Carnevale, G. 2013, Journal of Asian Earth Sciences, 62, 788, doi: 10.1016/j.jseaes.2012.11.033

Vögeli, N., Najman, Y., van der Beek, P., and others,. 2017, Earth and Planetary Science Letters, 471, 1, doi: 10.1016/j.epsl.2017.04.037

Wang, F., Li, S., Shen, X., Jie, Z., \& Yan, G. 1996, Science in China Series D, 39, 401

Wang, Y., Cerling, T. E., Quade, J., and others,. 1993, Climate Change in Continental Isotopic Records, 78, 241 
Wang, Y., \& Deng, T. 2005, Earth and Planetary Science Letters, 236, 322, doi: 10.1016/j.epsl.2005.05.006

Wei, Y., Zhang, K., Garzione, C. N., and others,. 2016, Scientific Reports, 6, 27508, doi: 10.1038/srep27508

White, P. D., \& Schiebout, J. 2008, Geological Society of America Bulletin, 120, 1347, doi: 10.1130/B25987.1

White, T., Bradley, D., Haeussler, P., \& Rowley, D. B. 2017, ${ }^{1025}$ The Journal of Geology, 125, 113, doi: 10.1086/690198 1026 White, T., González, L., Ludvigson, G., \& Poulsen, C. 2001, 1027 Geology, 29, 363, doi: 10.1130/0091-7613(2001)029/0363: $\mathrm{MCGHCO} \backslash 2.0 . \mathrm{CO} ; 2$

Williams, J. W., Grimm, E. C., Blois, J. L., and others,. 2018, Quaternary Research, 89, 156, doi: 10.1017/qua.2017.105

Winnick, M. J., Chamberlain, C. P., Caves, J. K., \& Welker, J. M. 2014, Earth and Planetary Science Letters, ${ }^{103}$ 406, 123, doi: 10.1016/j.epsl.2014.09.005

Winnick, M. J., Welker, J. M., \& Chamberlain, C. P. 2013, Climate of the Past, 9, 9, doi: 10.5194/cp-9-903-2013

Wolf, A., Roberts, W. H. G., Ersek, V., Johnson, K. R., \& Griffiths, M. L. 2020, Scientific Reports, 10, 16482, doi: 10.1038/s41598-020-73508-Z

Xia, Z., \& Winnick, M. J. 2021, Earth and Planetary Science Letters, 572, 117120, doi: 10.1016/j.epsl.2021.117120
1020 1021
Xu, Q., Ding, L., Hetzel, R., Yue, Y., \& Rades, E. F. 2015, Terra Nova, 27, 458, doi: 10.1111/ter.12180

Xu, Q., Ding, L., Zhang, L., and others,. 2013, Earth and Planetary Science Letters, 362, 31, doi: 10.1016/j.epsl.2012.11.058

Xu, Q., Liu, X., \& Ding, L. 2016, Geochemistry, Geophysics, Geosystems, 17, 4254, doi: 10.1002/2016GC006437

Zamarreno, I., Anadon, P., \& Utrilla, R. 1997, Sedimentology, 44, 159, doi: 10.1111/j.1365-3091.1997.tb00430.x

Zanazzi, A., Judd, E., Fletcher, A., Bryant, H., \& Kohn, M. J. 2015, Palaeogeography, Palaeoclimatology, Palaeoecology, 417, 561, doi: 10.1016/j.palaeo.2014.10.024

Zanazzi, A., Kohn, M. J., MacFadden, B. J., \& Terry, D. O. 2007, Nature, 445, 639, doi: 10.1038/nature05551

Zhisheng, A., Yongsong, H., Weiguo, L., and others,. 2005, Geology, 33, 705, doi: 10.1130/G21423.1

Zhuang, G., Hourigan, J. K., Koch, P. L., Ritts, B. D., \& Kent-Corson, M. L. 2011, Earth and Planetary Science Letters, 312, 152, doi: 10.1016/j.epsl.2011.10.005 